\title{
Agrophotovoltaic systems: applications, challenges, and opportunities. A review
}

\author{
Axel Weselek ${ }^{1}$ (1) $\cdot$ Andrea Ehmann $^{1,2} \cdot$ Sabine Zikeli $^{3} \cdot$ Iris Lewandowski $^{2} \cdot$ Stephan Schindele $^{4} \cdot$ Petra Högy $^{1}$
}

Accepted: 17 May 2019 / Published online: 19 June 2019

(C) INRA and Springer-Verlag France SAS, part of Springer Nature 2019

\begin{abstract}
The expansion of renewable energies aims at meeting the global energy demand while replacing fossil fuels. However, it requires large areas of land. At the same time, food security is threatened by the impacts of climate change and a growing world population. This has led to increasing competition for limited land resources. In this context, the combination of photovoltaics and plant production - often referred to as agrophotovoltaic (APV) or agrivoltaic systems - has been suggested as an opportunity for the synergistic combination of renewable energy and food production. Although this technology has already been applied in various commercial projects, its practicability and impact on crop production have hardly been investigated. In this review, we give a short summary of the current state of the art and prospective opportunities for the application of APV systems. In addition, we discuss microclimatic alterations and the resulting impacts of APV on crop production. Our main findings are that (1) crop cultivation underneath APV can lead to declining crop yields as solar radiation is expected to be reduced by about one third underneath the panels. However, microclimatic heterogeneities and their impact on crop yields are missing reference and thus, remain uncertain. (2) Through combined energy and crop production, APV can increase land productivity by up to $70 \%$. (3) Given the impacts of climate change and conditions in arid climates, potential benefits are likely for crop production through additional shading and observed improvements of water productivity. (4) In addition, APV enhances the economic value of farming and can contribute to decentralized, off-grid electrification in developing and rural areas, thus further improving agricultural productivity. As such, APV can be a valuable technical approach for more sustainable agriculture, helping to meet current and prospective needs of energy and food production and simultaneously sparing land resources.
\end{abstract}

Keywords Agrophotovoltaic $\cdot$ Agrivoltaic $\cdot$ Photovoltaics $\cdot$ Crop production $\cdot$ Microclimate $\cdot$ Agricultural yields

Axel Weselek

a.weselek@uni-hohenheim.de

1 Department of Plant Ecology and Ecotoxicology, Institute of Landscape and Plant Ecology, University of Hohenheim, Stuttgart, Germany

2 Department of Biobased Products and Energy Crops, Institute of Crop Science, University of Hohenheim, Stuttgart, Germany

3 Center for Organic Farming, University of Hohenheim, Stuttgart, Germany

4 Division Photovoltaics, Group PV Power Plants, Fraunhofer Institute for Solar Energy Systems ISE, Freiburg, Germany

\section{Contents}

1. Introduction

2. Agrophotovoltaic systems: Application and current status.

2.1 The concept of APV.

2.2 Existing projects and technologies.

2.3. Agronomic aspects.

2.3.1. Field management implications

2.3.2 Microclimatic alterations and their impact on crop cultivation.

2.3.2.1. Effect of shading on yield and quality.

2.4 Modelling approaches in APV research.

3. Outlook and future application opportunities.

4. Conclusion

Acknowledgments

References 


\section{Introduction}

The development of renewable energy sources as a means of meeting the global energy demand and simultaneously replacing fossil fuels as one of the key drivers of climate change has become one of the major societal challenges of our time. In this context, photovoltaic (PV) systems offer great potential and are considered even more efficient in capturing sunlight energy than photosynthesis (Blankenship et al. 2011). This, and the fact that the installation of these systems on open areas is the lowest cost option (Fraunhofer ISE 2015), has also led to PV systems being established on agricultural land. However, this can result in a land-use conflict between energy and food production, and can be of major concern especially in regions with limited land area or a dense population. The extensive installation of large-scale ground-mounted PV facilities has led to dwindling societal acceptance in some regions and increasing concerns about the loss of arable land for more profitable PV energy production (Nonhebel 2005). In view of this conflict, the development of agrophotovoltaic (APV) systems can be seen as a way of combining PV and food production on the same land area (Fig. 1). The concept of APV was introduced by Goetzberger and Zastrow (1982) more than three decades ago. Recently, several commercial APV plants and small-scale research facilities have been established around the world (Obergfell et al. 2017). As demonstrated by several studies, APV can increase land productivity (Dupraz et al. 2011a; Elamri et al. 2018; Valle et al. 2017). It thus offers great potential as a resource-efficient, co-productive renewable energy system in regions with dense populations or limited land area, such as mountainous regions and islands (Dinesh and Pearce 2016). However, its highest potential is anticipated in semi-arid and arid regions, where various synergistic side effects can be expected (Marrou et al. 2013a; Ravi et al. 2016). Here, crop cultivation often suffers from the adverse effects of high solar radiation and concomitant water losses. Water use efficiency has been shown to increase underneath the panels in PV installations (Hassanpour Adeh et al. 2018), and similar results have been observed in APV systems (Elamri et al. 2018; Marrou et al. 2013a). These findings are becoming even more relevant, as water demand for irrigation is expected to increase in prospective future climatic conditions (Elamri et al. 2018; Hannah et al. 2013). In addition to improved water productivity, crops cultivated in arid climates may also directly benefit from the reduction in solar radiation through the PV panels (Harinarayana and Vasavi 2014). Besides its impacts on crop production, the implementation of APV enhances the profitability of farming by generating additional income through energy production (Dinesh and Pearce 2016; Malu et al. 2017) and further may improve rural, off-grid electrification as part of decentralized energy systems (Burney et al. 2010; Harinarayana and Vasavi 2014; Malu et al. 2017; Silva Herran and Nakata 2012). Therefore, APV can be an important component of future renewable energy production systems, while simultaneously ensuring food production and the economic viability of agriculture (Dinesh and Pearce 2016). However, regarding the land-use conflict, the actual value of APV as combined food and energy production system requires a clear demarcation from primarily energy producing PV systems by maintaining a sufficient crop productivity. First field experiments addressing the utilization of this technology and its impact on crop cultivation have shown that the land use efficiency of combined PV and food-crop systems can be improved compared to separate production (Dupraz et al. 2011a; Marrou et al. 2013c). Electrical yield and economic profit can be enhanced by increasing the PV module density, which simultaneously reduces cropavailable radiation (Dupraz et al. 2011a). This emphasizes the importance of finding an appropriate relation between food and energy production. The impact of APV on crop
Fig. 1 Potatoes growing underneath an APV facility. The facility was set up within the project APV RESOLA and is located at Heggelbach, administrative district of Sigmaringen, Germany. Its implementation in agricultural production is currently investigated (source: University of Hohenheim)

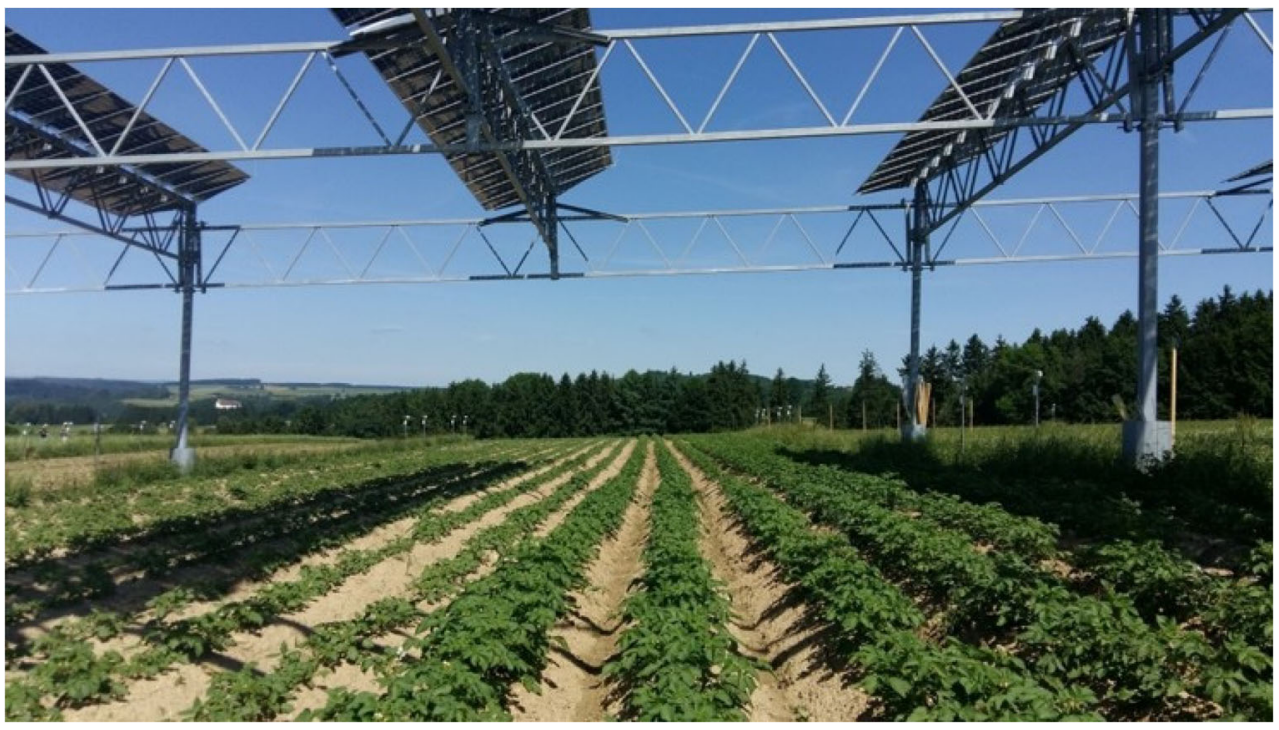


development and performance is inevitable, but has so far only been scientifically investigated for a small number of crop species, such as lettuce, cucumber and durum wheat (see e.g. Marrou et al. 2013c). This shows the necessity for further research. This review paper summarizes existing literature on APV systems and gives a general overview of the APV technology with present-day application examples, recent developments and prospective application areas. First reports on experiences with crop production in APV systems are analysed with the aim of assessing current knowledge on APV and the effects of shading on crop production. In addition, we discuss various technical and agronomic aspects of APV systems, focusing in particular on their impact on microclimate and crop production to evaluate their applicability in agricultural food production.

\section{Agrophotovoltaic systems: application and current status}

\subsection{The concept of APV}

The concept of agrophotovoltaics (APV) was initially proposed in the year 1982 by Goetzberger and Zastrow as a means of modifying solar power plants to enable additional crop production on the same area. Their idea was to raise the solar collectors to $2 \mathrm{~m}$ above the ground and increase the spacing between them to avoid excessive shading of the crops. They assumed that these systems would only require one third of the incoming radiation and that further technical improvements could increase their suitability for application in crop production. It took about three decades until this concept, referred to as agrophotovoltaic, agroPV, agrivoltaic or solar sharing, was implemented in various projects and pilot plants worldwide. Calculations have shown that the application of this technical approach can increase farms' incomes by over $30 \%$, if yield losses through shading effects are minimized by the selection of suitable crops (Dinesh and Pearce 2016). Dupraz et al. (2011a) applied the Land Equivalent Ratio (LER), a method of evaluating the productivity of an intercropping system in comparison to a single-crop cultivation system (Mead and Willey 1980), to determine the advantages of a dual-use APV system over a single-crop and PV production. Their simulations revealed that overall land productivity can be increased by up to $70 \%$ in APV systems. In a recent modelling study addressing biogas maize production, Amaducci et al. (2018) showed that renewable-energy land productivity can be even doubled by APV compared to the separate production of maize and energy with groundmounted PV modules. In 2010, Dupraz et al. (2011a) set up an APV test facility to validate their assumptions. In order to find a well-balanced combination of food and energy production, they tested two different densities of PV modules. While
PV yield increased with panel density (Dupraz et al. 2011a), the optimum conditions for simultaneous crop production were found under less dense PV modules (Marrou et al. 2013c). The solar panels were raised to 4-m clearance height to allow common agricultural machinery to pass underneath. A number of studies on crop cultivation between groundmounted PV rows designate such systems as agrivoltaic (Hassanpour Adeh et al. 2018; Santra et al. 2017). However, in this review, we make a clear distinction between groundmounted PV systems and our definition of APV, where the PV facility is lifted off the ground and further adapted to meet the requirements of sufficient crop production underneath.

The technical features of APV systems are steadily being refined and vary between regions and companies. Some APV projects already use mobile PV modules that enable solar tracking. These maximize photovoltaic yield and at the same time improve light availability allowing sufficient crop growth (Valle et al. 2017). This approach has recently been investigated by Valle et al. (2017) with 1-axis orientable PV systems and different tracking settings. They showed that the performance of both energy and crop production can indeed be further increased by the application of dynamic PV modules. In the regular solar-tracking mode, the modules automatically adjusted to the solar altitude, optimizing electricity generation and also increasing solar radiation at plant level compared to fixed PV modules (Valle et al. 2017). To increase the radiation transmitted to the crop and thus further improve its productivity, Valle et al. (2017) also tested a controlled tracking mode incorporating diurnal changes in solar radiation. In the morning and late afternoon hours, the position of the photovoltaic panels was altered to reduce crop shading, whereas at solar noon, shading was increased to reduce evapotranspiration and adverse effects of high temperature and excessive radiation on plant growth. As a result, crop biomass increased under controlled tracking, but electricity production declined compared to the regular solar-tracking mode (Valle et al. 2017). Solar tracking technology has already been implemented in various commercial APV facilities (Table 1; see also in Section 2.2) and recently also been investigated in PV greenhouses (Li et al. 2018). However, the extent of radiation available underneath the APV array is affected more by panel density than by panel mobility (Amaducci et al. 2018). In addition to improving light-use efficiency for both PV and crop production, mobile PV panels can also be used to improve rainfall distribution underneath APV systems (Elamri et al. 2017; see also in Section 2.3.1). The incorporation of the APV concept has recently also been considered in cropping systems such as viticulture and in intensive fruit production, where the utilization of supporting structures is already common practice and synergistic effects may exist (Sun'Agri 2018). A study modelling the APV potential of Indian grape farms revealed that the annual income of these farms could be multiplied compared to conventional farms without APV, while still maintaining 
Table 1 Overview of existing APV facilities with technical specifications and crops cultivated underneath. The numbers in the first column correspond to those in Fig. 2

\begin{tabular}{|c|c|c|c|c|c|c|c|}
\hline No. & Location & Country & $\begin{array}{l}\text { Electricity yield } \\
{\left[\mathrm{kWh} \mathrm{a}^{-1}\right]}\end{array}$ & $\begin{array}{l}\text { Capacity } \\
{[\mathrm{kWp}]}\end{array}$ & $\begin{array}{l}\text { Solar } \\
\text { tracking }\end{array}$ & Cultivated crops & Source \\
\hline \multicolumn{8}{|c|}{ Commercial facilities } \\
\hline 1 & Monticelli D’Ongina & Italy & $4,842,000$ & 3230 & Yes & Winter wheat, maize & $\begin{array}{l}\text { Praderio and Perego (2017); } \\
\quad \text { Rem Tec (2017a) }\end{array}$ \\
\hline 2 & Castelvetro & Italy & $1,890,000$ & 1294 & Yes & Winter wheat, maize & $\begin{array}{l}\text { Praderio and Perego (2017); } \\
\text { Rem Tec (2017a) }\end{array}$ \\
\hline 3 & Virgilio & Italy & $3,325,000$ & 2150 & Yes & Winter wheat, maize & $\begin{array}{l}\text { Praderio and Perego (2017); } \\
\quad \text { Rem Tec (2017a) }\end{array}$ \\
\hline 4 & Abruzzo & Italy & Unknown & 800 & Yes & $\begin{array}{l}\text { Pasture, tomato, } \\
\text { watermelon, wheat }\end{array}$ & Corditec (2017) \\
\hline 5 & Anhui province & China & 887,000 & 544 & Yes & Unknown & $\begin{array}{l}\operatorname{Rem~Tec~(2017a)~} \\
\quad(\operatorname{Rem~Tec~2017b)~}\end{array}$ \\
\hline 6 & Zhejiang province & China & $40,000,000$ & 30,000 & Yes & Rice & Tonking New Energy (2018) \\
\hline \multicolumn{8}{|c|}{ Research facilities } \\
\hline 7 & Arizona & USA & Unknown & Unknown & No & $\begin{array}{l}\text { Cabbage, chard, kale, } \\
\text { tomato, onion }\end{array}$ & Tricoles (2017) \\
\hline 8 & Montpellier & France & Unknown & Unknown & Partly & $\begin{array}{l}\text { Cucumber, durum wheat, } \\
\text { French bean, lettuce }\end{array}$ & $\begin{array}{l}\text { Marrou et al. (2013b); } \\
\text { Valle et al. (2017) }\end{array}$ \\
\hline 9 & Heggelbach & Germany & 244,401 & 194 & No & $\begin{array}{l}\text { Winter wheat, clover grass, } \\
\text { celeriac, potato }\end{array}$ & Authors' project \\
\hline 10 & Santiago de Chile & Chile & 21.437 & Unknown & No & $\begin{array}{l}\text { Various cabbage varieties } \\
\text { (broccoli, cauliflower, kale), } \\
\text { potato, pumpkin }\end{array}$ & $\begin{array}{l}\text { Fraunhofer Chile Research (2017b); } \\
\quad \text { Fraunhofer Chile Research }(2017 \mathrm{c})\end{array}$ \\
\hline 11 & Chiba Prefecture & Japan & 35,000 & Unknown & No & $\begin{array}{l}\text { Cabbage, cucumber, } \\
\text { eggplant, peanut, } \\
\text { tomato, taro, yam }\end{array}$ & Movellan (2013) \\
\hline
\end{tabular}

grape yields (Malu et al. 2017). Extrapolating to nationwide scale (i.e. taking the entire Indian grape cultivation area of about 34,000 ha into consideration), Malu et al. (2017) calculated an APV output of 16,000 GWh, enough to meet the energy demand of more than 15 million people.

The most promising potential of APV systems can be expected in arid regions where various synergistic effects may occur. Crop production may benefit from increased water savings by reduction in evapotranspiration and adverse effects of excessive radiation, while economic viability is increased and rural electrification is made possible (Majumdar and Pasqualetti 2018; Ravi et al. 2016). As Amaducci et al. (2018) have shown, reduced soil evaporation under APV may also diminish yield losses in dry years and improve yield stability.

\subsection{Existing projects and technologies}

Several commercial and research APV facilities have been realized in the last few years (Fig. 2; Table 1). From 2004 onwards, a number of small-scale APV plants have been built in Japan (Movellan 2013). These systems, referred to as 'solar sharing', consist of PV panels mounted on poles with a 3-m ground clearance. They combine solar energy production with the cultivation of various local food crops such as peanuts, yams, eggplants, cucumbers, tomatoes, taros and cabbages. A few APV projects have also been implemented in Europe in recent years. In addition to several research facilities in France and Germany, three commercial APV projects, patented as 'Agrovoltaico', have been realized in North Italy. The installed systems have capacities of up to $1500 \mathrm{kWp}$ using mounted solar modules (4-5 m height) with solar-tracking technology (Casarin 2012; Rem Tec 2017a). Another APV field in Abruzzo uses 67 stand-alone solar trackers with various crops such as tomatoes, watermelons and wheat grown underneath and generates a total output of $800 \mathrm{kWp}$ (Corditec 2017).

The first pilot APV research facility in the South of France was divided into two subsystems with different PV panel densities to investigate the effect on solar distribution and energy yield (Dupraz et al. 2011a). In a follow-up study, Marrou et al. (2013a) performed a field trial with four lettuce varieties to confirm simulated results. They investigated the impact of APV systems on growth, morphology, yield and microclimatic conditions. To test its applicability in crop rotations, further species including cucumber, French bean and durum wheat were cultivated. In their experiments, the authors used an APV system with fixed mounted solar panels. Marrou et al. (2013a) suggested that further improvements in crop and PV performance might be achieved using 
Commercial facilities:

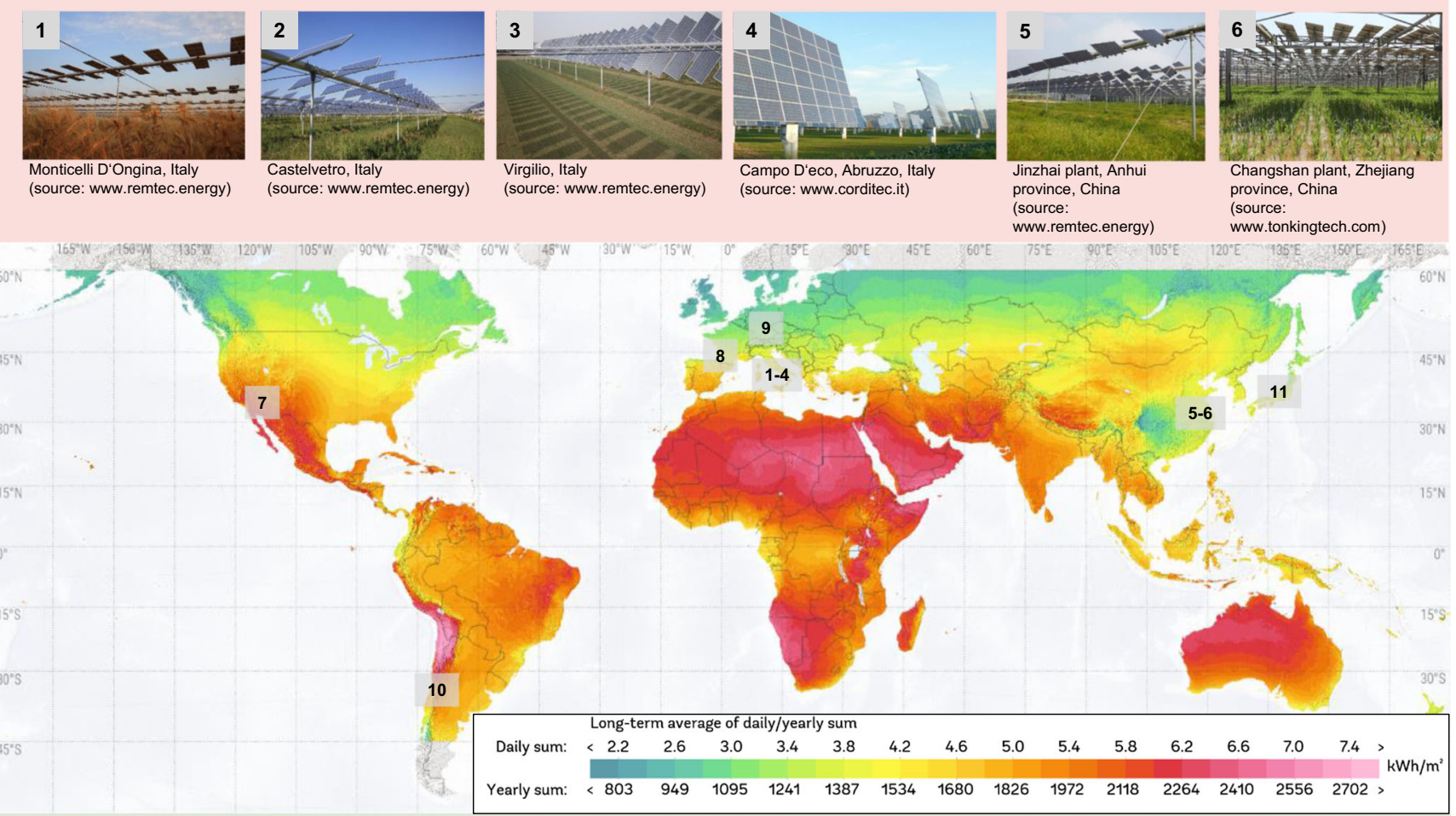

Research facilities:
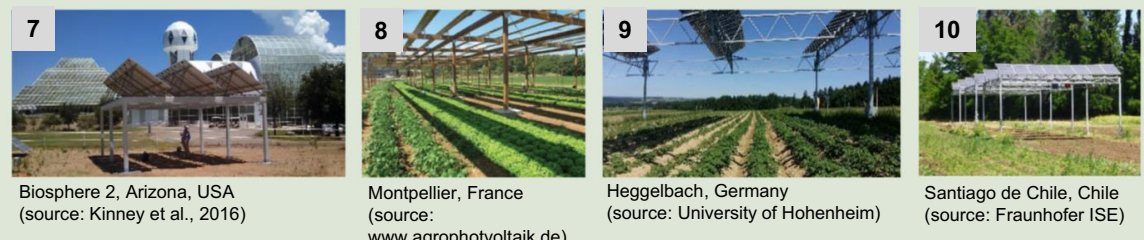

Santiago de Chile, Chile Montpellier, France (source:

eggelbach, Germany (source: Fraunhofer ISE)

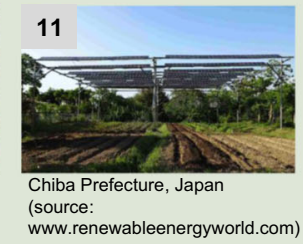

Fig. 2 Overview of APV projects and facilities with location. The colour gradient indicates the long-term average of daily/yearly sum of global horizontal radiation $\left[\mathrm{kwh} / \mathrm{m}^{2}\right]$. The numbers indicate the location of the

solar-tracking technology. As described above, this approach has been adopted in another study that addresses the use of solar trackers and the potential benefits for energy and crop production compared to systems with stationary PV panels (Valle et al. 2017). All commercial plants listed in Table 1 are equipped with solar-tracking systems, but only one research facility has a partly tracking system. In Germany, the Fraunhofer Institute for Solar Energy Systems (Fraunhofer ISE) is at the forefront of APV research. In 2016, the Fraunhofer ISE constructed an APV research plant in South Germany, which is described in more detail in the next section. In cooperation with their Chilean subsidiary Fraunhofer Center for Solar Energy Technologies (Fraunhofer CSET), three further pilot plants have been realized near Santiago de Chile to investigate the implementation of APV and its impact on field crops in different climate zones (Fraunhofer Chile Research 2017a; Fraunhofer 2017). In the USA, a small-scale APV research plant has recently been installed in Arizona as part of the described facilities (Global horizontal irradiation map ( 2018 The World Bank, Solar resource data: solargis.com, used under CC BY 3.0 IGO, modified from original)

Biosphere 2 research facility (The University of Arizona 2018; Table 1) and it is planned to set up further testing sites in rural Arizona and northern Mexico (Kinney et al. 2016; Pallone 2017). In addition to the potential benefits of APV for crop cultivation through alterations in microclimate, the researchers are focusing on how the crop canopy might provide a cooling effect on PV modules in arid regions. While in Europe and America mainly small-scale research and a few medium-scale commercial APV facilities have so far been established, China is already implementing this technology on a large scale (Huawei FusionSolar 2017; Rem Tec 2017a; Tonking New Energy 2018). APV plants with capacities up to $700 \mathrm{MWp}$ and various technical add-ons, such as irrigation systems and dual-axis tracking, have recently been set up in several regions (Huawei FusionSolar 2017; Tonking New Energy 2018). Various agricultural crops including rice and forage grasses are cultivated. According to the executing company, this technology enables the temperature to be lowered and an 
appropriate microclimate for crop cultivation to be created underneath the panels by reducing irradiation by about $30 \%$ (Tonking New Energy 2018). This could be advantageous in hot regions like Southern China. The currently most powerful APV facility with a capacity of $700 \mathrm{MWp}$ has recently been put into operation in Ningixia (Huawei FusionSolar 2017).

Although the APV technology is increasingly being applied all over the world, there is very little accompanying scientific research to examine its impacts on agronomic parameters, such as crop performance and crop yields. In addition to regions with land limitation, arid areas with a high solar radiation are considered the most promising locations for the application of the APV technology in terms of electricity output and synergistic effects on crop cultivation. However, so far, only the Biosphere 2 research facility and the Fraunhofer pilot plants in Chile are located in such regions (Fraunhofer Chile Research 2017b; The University of Arizona 2018). APV plants in Southern Europe and South China give first indications for the potential of APV systems in dry climates. To determine their full potential, however, further investigations are necessary, with results being made accessible through publications.

The project APV-RESOLA (AGROPHOTOVOLTAICS Resource-Efficient Land Use) was launched in 2015 under the German Federal Ministry for Education and Research (BMBF) funding schemes. Preliminary simulations were performed by the Fraunhofer ISE during patent development for the technical optimization of APV systems (patent EP 2811819 B1). An APV research plant was then installed onfarm in 2016 near Lake Constance in south Germany. This region was chosen because of its low share $(6 \%)$ of renewable-based electricity generation in gross electricity consumption (Energieagentur Ravensburg gGmbH 2012) in comparison to the national average of 17\% in 2010 (BMWi 2016). In addition, the promotion of renewable energies in touristic regions like the Lake Constance area is facing a lack of acceptance as wind turbines and PV plants are considered detrimental to landscape scenery. This APV research plant is used to examine the impacts of the technology with regard to various aspects including renewable energy production, economic feasibility, crop production, social acceptance and technological design. It has a total size of 0.3 ha and a capacity of $194 \mathrm{kWp}$. The solar panels are mounted on stilts with a vertical clearance of $5 \mathrm{~m}$. The facility has a number of specific features to enable uniform light distribution for the simultaneous optimization of PV and photosynthetic yield, (Beck et al. 2012; Fraunhofer ISE patent EP 2811819 B1). The fixed PV panels are oriented in a south-west direction with a tilt angle of $20^{\circ}$ and a row spacing of $6.3 \mathrm{~m}$. The plant-available photosynthetically active radiation (PAR) below is predicted to reach values of about $60 \%$ of total PAR above the array with variations between winter and summer (Obergfell et al. 2017). Bifacial PV modules are used to further enhance PV energy yield. These are able to utilize light from both sides and thus also intercept reflected radiation. The system was set up on an arable field of a commercial farm managed according to biodynamic principles in order to investigate its practical suitability for farm machinery and impact on crop rotation. The main motive for the farmers to join the project was to become energy self-sufficient or even produce excess energy for the neighbouring village. Four crops (celeriac, potato, winter wheat and clover grass) were chosen to represent a typical organic crop rotation. These were cultivated both underneath the APV facility and on an adjacent reference site without PV modules. The impacts of APV on the environment and agriculture are investigated based on a number of microclimatic and agronomic parameters including crop performance, crop yield and crop quality of the harvested products as well as the impact on biodiversity. Microclimate monitoring is performed by 32 stations allocated to the different cultures and treatments. They record PAR, soil moisture, soil temperature, humidity and air temperature in half-hour intervals, thus providing a high temporal resolution. Observations from the first crop year are discussed in the next section. Data on yield and quality of harvested products cannot be presented until after the second crop year. Additional accompanying research is being performed by the Fraunhofer ISE and the Institute for Technology Assessment and Systems Analysis (ITAS) to assess the electrical and economic performance of the APV system and also its social acceptance.

\subsection{Agronomic aspects}

This section discusses the impacts of APV technology on agriculture. Its utilization will most likely not only affect farming in terms of crop cultivation, but also agricultural practice. For this reason, we distinguish between its impact on technical aspects and operating procedures in field management, as well as the effects of APV on microclimate conditions and its consequences for crop cultivation. The usage of crop models to evaluate the effects of environmental impacts on crop production is currently also investigated for its application in APV research and thus, will also be discussed within this section.

\subsubsection{Field management implications}

The application of APV systems imposes several requirements on crop production and its technical management. First of all, the mounting structure of APV arrays needs to be adjusted to the requirements of the agricultural machinery used. As already mentioned, the PV panels have to be raised to an adjusted overhead clearance to permit conventional agricultural machines to pass. For cereal cropping with its large combined harvesters in particular, a clearance of at least 4-5 m is required. To prevent the loss of utilizable land, the distance between the pillars needs to be suitable for planting distances 
and working widths of the machinery. Our APV field trial showed that driving machinery underneath the APV facility and the arrangement of driving lanes require some experience and the driver's increased attention to prevent damage to the facility. In addition, the working width needs to be adjusted to the distance between the stilts. Given the fast development of autonomous driving and precision-farming applications, we expect these restrictions to be of minor importance for future large-scale arable farming. However, a certain loss of production areas between the stilts that are difficult to reach by agricultural machinery is inevitable and should be considered when predicting impacts on agricultural yields. As stated by Praderio and Perego (2017), at least $2 \%$ of the land will be occupied by the pillars of the mounting structure. Their anchorage can be accomplished in several ways. In the APV facility at Heggelbach, a special anchoring system (Obergfell et al. 2017; Spinnanker $\mathrm{GmbH}$ ) was used to avoid the construction of concrete foundations in order to protect the soil and facilitate the complete removal of the construction.

Various construction modifications should be anticipated to minimize alterations in microclimatic conditions (discussed in next section). The application of PV panels can lead to increased water runoffs, causing an unbalanced water distribution with distinct moist patches under the lower panel edge and sheltered areas directly under the panel (Elamri et al. 2017). During heavy rainfall, strong runoffs from the PV modules can lead to soil erosion (Elamri et al. 2017) and the formation of gullies. The latter was also observed in our own APV trial. However, the problem only occurred in early development stages of wheat, potato and root celery i.e. when the soil was either not covered or barely covered by the crops. In a recent study dealing with the effects of solar panels on unirrigated pasture, Hassanpour Adeh et al. (2018) found higher amounts of soil moisture retained underneath the panels of a ground-mounted PV system. The heterogeneity of rain distribution in APV systems was recently described by Elamri et al. (2017). Their results reveal that technical features need to be considered to improve rain distribution or for the collection of run-offs from the panels. Their study used PV panels with adjustable tilt angles and found rain distribution to be most heterogeneous with flat panels $\left(0^{\circ}\right.$ tilt angle) and least heterogeneous with panels in an either directly facing the wind or in the opposite direction. A strategy using a time-variable tilt angle depending on wind direction was found to be most effective at achieving a virtually uniform rainfall distribution (Elamri et al. 2017). In a model (see also Section 2.4), Elamri et al. (2017) also found the angle of incidence of rainfall to be a key variable in the determination of rainfall distribution heterogeneity. If the APV facility is implemented on a hillside, one approach for both, the utilization of the inaccessible area between the stilts and the mitigation of the soil erosion mentioned above, can be the planting of hedges or of perennial biomass crops in between the stilts.
Several technical and mechanical adjustments can be made to minimize the reduction in solar radiation by the PV panels and the resulting disadvantages for crop cultivation. The density of the PV arrays needs to be lower than for conventional ground-mounted PV facilities in order to maintain acceptable agricultural yields. A row distance of about $3 \mathrm{~m}$ is assumed to be adequate to allow sufficient quantities of light to reach the crop canopy while still achieving satisfactory energy yields. As part of a patent development (Fraunhofer ISE patent EP 2811819 B1), Beck et al. (2012) observed in their simulation that directing the PV arrays towards southwest or southeast was most suitable to achieve uniform light conditions under the panels. This also resulted in a predicted reduction in electricity yield of 5\% compared to conventional south-oriented arrays. The optimum module tilt angle depends on the geographical location; in Central Europe it is around 20-25 (Beck et al. 2012; Dupraz et al. 2011a; Obergfell et al. 2017). It should be noted that a small inclination angle can lead to increased dust depositions as these are not washed off by the rain so easily. The same applies to snow covering in regions with regular snowfall. Dupraz et al. (2011a) have also suggested modifying the panel tilt during certain periods of the year that correspond to light-sensitive stages of crop development. For example, during emergence and pre-anthesis, wheat has been shown to be very sensitive to shading in terms of grain yield (Fischer 1985). Mobile PV modules allow sun tracking to be automatically controlled to accommodate both the specific needs of crops as well as diurnal and seasonal variations in light intensity (Valle et al. 2017).

Further technical innovations to current technology include semi-transparent (Cossu et al. 2016; Park et al. 2010), wavelength-selective (Loik et al. 2017) and bifacial PV modules (Schmid and Reise 2015). Li et al. (2018) recently combined some of these technical innovations in a greenhouse study using bifacial semi-transparent PV-modules with an adjustable tilt angle instead of conventional blinds. Depending on the solar irradiance level, the PV modules can be either tilted parallel to the greenhouse ceiling to generate electricity and shade the cultivated crops, or vertical to maximize crop intercepted radiation when solar irradiance level is low ( $\mathrm{Li}$ et al. 2018). One concern is the decline in electrical performance through dust deposition on the panel surface as a consequence of agricultural management e.g. tillage and harvesting (Dinesh and Pearce, 2016). Notably in regions with low precipitation or extended dry periods (e.g. monsoon climates), the occasional cleaning of the module surface should be considered to avoid declining electricity yields through dust deposition (Dinesh and Pearce 2016). As suggested by Ravi et al. (2016), this could be managed by integrating irrigation systems and PV cleaning to avoid additional water consumption (Fig. 3). Another preliminary result observed in the APV trial in Heggelbach, is the slight delay in development of crops grown under APV, which has also been observed in other 
Fig. 3 Integration of PV module surface cleaning with irrigation system. Its application is also conceivable in APV systems. Run-off water of the PV module cleaning system can be collected or directly used to irrigate crops cultivated underneath (source: Ravi et al. (2016))

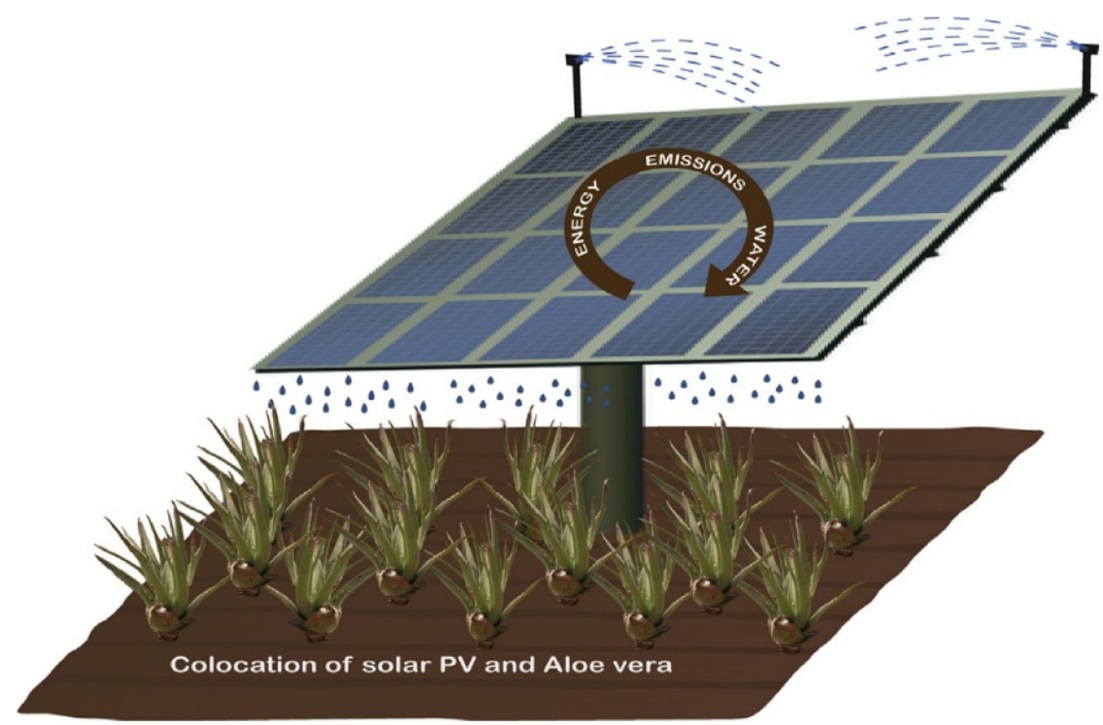

studies dealing with the impacts of APV and shade on crop production (Elamri et al. 2018; Rotundo et al. 1998). This is probably due to altered microclimatic conditions and also has an influence on field management as well as the marketing strategy of some crops (Elamri et al. 2018; Rotundo et al. 1998).

\subsubsection{Microclimatic alterations and their impact on crop cultivation}

In addition to the field management aspects mentioned above, one of the most important issues for agricultural practice underneath an APV array is the alteration of microclimate conditions and the resulting consequences for crop cultivation. While the reduction in solar radiation underneath the APV canopy is expected to be the most apparent change, several other microclimate factors may also be altered. One microclimate factor that is directly influenced by solar radiation is air temperature. Marrou et al. (2013c) did not find any significant changes in daily mean temperatures and thermal time between an APV trial and an unshaded control plot at the French location of Montpellier. On a few days with low wind speed or high solar radiation, the temperatures underneath the panel tended to be higher (Marrou et al. 2013b). However, other studies found that soil temperature (Ehret et al. 2015) and maximum air temperature (Pang et al. 2017) decreased under shaded compared to full-sun conditions. This inconsistency may be due to the direct effects of the solar panels on air temperature observed in studies with ground-mounted solar parks (Barron-Gafford et al. 2016; Hassanpour Adeh et al. 2018) and the heterogeneous shading conditions underneath APV facilities. In contrast, Armstrong et al. (2016) found mean air temperature under PV panels to be unaffected, with diurnal variation in air temperature under the panels being lower due to higher minimum temperatures and lower maximum temperatures. Nevertheless, these results should not be directly transferred to APV systems where the PV modules are high above the crop canopy. However, potential impacts of air and canopy temperature changes through shading on crop cultivation need to be considered, particularly in regions with high solar irradiation. Excessive heat may have negative effects on crop yields, as has been shown for example for potatoes, where marketable tuber yields decreased (Kim et al. 2017). Temperature and radiation - described by the photothermal quotient - are in general two of the most important determinants of cereal grain yields (Fischer 1985). In addition, temperature can affect nutritional quality, for example fatty acid composition of oilseed rape (Gauthier et al. 2017; Izquierdo et al. 2009) and starch content of potatoes (Krauss and Marschner 1984). While air temperatures tended to be higher, soil temperatures decreased underneath APV, whereas crop temperatures of durum wheat, lettuce and cucumber cultivated under APV decreased during the day-time and increased during the night-time (Marrou et al. 2013b).

As described in the preceding paragraph, the use of a solar panel canopy inevitably leads to an altered water distribution underneath (Dupraz et al. 2011a; Elamri et al. 2017; Hassanpour Adeh et al. 2018). After heavy rainfall, direct water runoffs onto the soil surface can increase the risk of soil erosion, while in more sheltered parts, unevenly distributed rainfall can lead to diminished water availability (Elamri et al. 2017). Beside these drawbacks, this sheltering by the PV panels could also help reduce the infestation of fungal diseases after persistent rainfall. The severity of anthracnose, one of the major post-harvest diseases in mangos grown in humid regions that often occurs after rainy seasons (Arauz 2000), has been found to decrease under a plastic roofing (Jutamanee et al. 2013). Comparable results have been observed by Du et al. (2015), who also found the severity of several fungal diseases to be reduced in sheltered grapevines in rainy regions of China. However, it should be noted, that in 
these studies completely sheltered crop stands are compared with non-sheltered crop stands. As only about one third of the total area is covered in APV systems (depending on configuration, size and density of installed modules), it remains doubtful whether the sheltering will have significant effects on disease infestation of the cultivated crops. In addition to the potential problems concerning water distribution, water balance in general may change under an APV system. Marrou et al. (2013a) reported that evapotranspiration is reduced under PV arrays due to both diminished evaporation and transpiration as a consequence of the light reduction. However, they found that the effect depended on the crop species cultivated, as evaporation is driven by crop cover rate. Under APV, the crop cover rate increased for lettuce, for example, but decreased for cucumber. Marrou et al. (2013a) concluded that APV systems can improve water use efficiency (WUE) and help prevent water losses under dry climates, if suitable crop species are chosen. This is in accordance with findings for citrus grown under shading nets, where WUE increased with lower solar irradiation (Medina et al. 2002). In simulations based on data from a 40-year period, Amaducci et al. (2018) found that cultivating maize under APV in non-irrigated conditions reduced soil evaporation and also increased average yield. The highest yield variation was obtained under full-sun conditions. Thus, they concluded that APV may lead to yield stabilization, mitigating yield losses in dry years (Amaducci et al. 2018).

\subsubsection{Effect of shading on yield and quality}

The extent of the reduction in solar radiation under an APV canopy very much depends on the seasonal solar altitude, the position underneath the array and the technical implementation of the facility. The latter includes orientation, tilt angle and size of the panels as well as the distance between them (Beck et al. 2012; Dupraz et al. 2011a). Due to the arrangement of the PV modules, shading underneath the facility is not uniform and varies during the day depending on solar altitude. In studies with APV systems adapted for crop production, for example through a reduced module density, crop-available radiation was predicted to reach values ranging between 60 and $85 \%$ of that in open-field conditions (Dupraz et al. 2011a; Majumdar and Pasqualetti 2018; Obergfell et al. 2017; Praderio and Perego 2017). This effect will be less distinct in smaller APV facilities due to border effects, especially when the sun is low and can reach the ground from the sides. In a field experiment where different lettuce varieties were cultivated under an APV facility, Marrou et al. (2013c) found that with reduced PV module density with a panel row distance of $3.2 \mathrm{~m}$, up to $73 \%$ of incoming radiation was available at plant level. On average, the lettuce yields were $81-99 \%$ of the full-sun control yields, with two varieties even exceeding the control values. In simulations performed with climate data from the last 37 years (1975-2012), Praderio and Perego (2017) found that average yields of maize and wheat grown under APV would only be reduced by about $0.5-1.5 \%$. However, it remains doubtful whether such yields can be achieved in practice. In a modified crop model adapted to the shading conditions underneath APV, Homma et al. (2016) found a $20 \%$ reduction in solar radiation led to a $20 \%$ reduction in rice yields. They concluded that sufficient light availability during early growth periods is an important yield factor.

Apart from the studies mentioned above, there is very little information on the effects of APV on crop production. Hence, information on the issue can only be taken from studies with comparable conditions, such as agroforestry experiments or studies with artificial shade. A brief summary of the existing literature addressing the impact of shading on plant development and yield is shown in Table 2. For reasons of comparability, only field experiments with artificial shade (mostly created by shading cloths or nets) were considered. As in most of these studies shade was provided by netting over the entire study area, the achieved uniform shading conditions are not the same as the dynamic shading patterns underneath an APV facility. Hence, the results of these studies should be treated with caution and cannot be directly transferred to APV systems. In most of the studies, different shading intensities were applied. In order to distinguish between intensities, we use the terms "moderate shading" (up to 50\% reduction compared to full sunlight) and "severe shading" (more than 50\% reduction compared to full sunlight) in the following text. These terms are only used to divide the shading intensities applied into two categories and are not intended as an assessment of the impact on crop production. For example, moderate shading conditions can potentially lead to severe results with regard to crop yield and quality as shown for potatoes (Sale 1973). As crop-available radiation under APV is reduced by about $15-40 \%$, these light conditions correspond to moderate shading (Amaducci et al. 2018; Dupraz et al. 2011a; Marrou et al. 2013b).

There is a strong correlation between grain yield and irradiance in cereals such as wheat (Artru et al. 2017; Dufour et al. 2013; Jedel and Hunt 1990; Li et al. 2012; Mu et al. 2010), rice (Islam and Morison 1992) and maize (Jia et al. 2011; Reed et al. 1988). The extent of yield reduction depends on the shading intensity, time period, and at which stage of crop development the shading is applied. For example, in rice, the yield reduction can reach up to $73 \%$ under severe shading conditions with a reduction of incoming radiation up to $77 \%$ (Islam and Morison, 1992). In previous experiments with wheat, Fischer (1985) showed that this decrease in yield is due to both, a reduced number of grains per spike and spikes per unit area and also varies with the crop phenological stage at which shading is applied. While the wheat crops were most sensitive to shading in the period 30 days prior to flowering, treatments ending 45 days before anthesis did not show any significant effects. These results are in agreement with findings in rice, where a slight shift in light intensity during the 


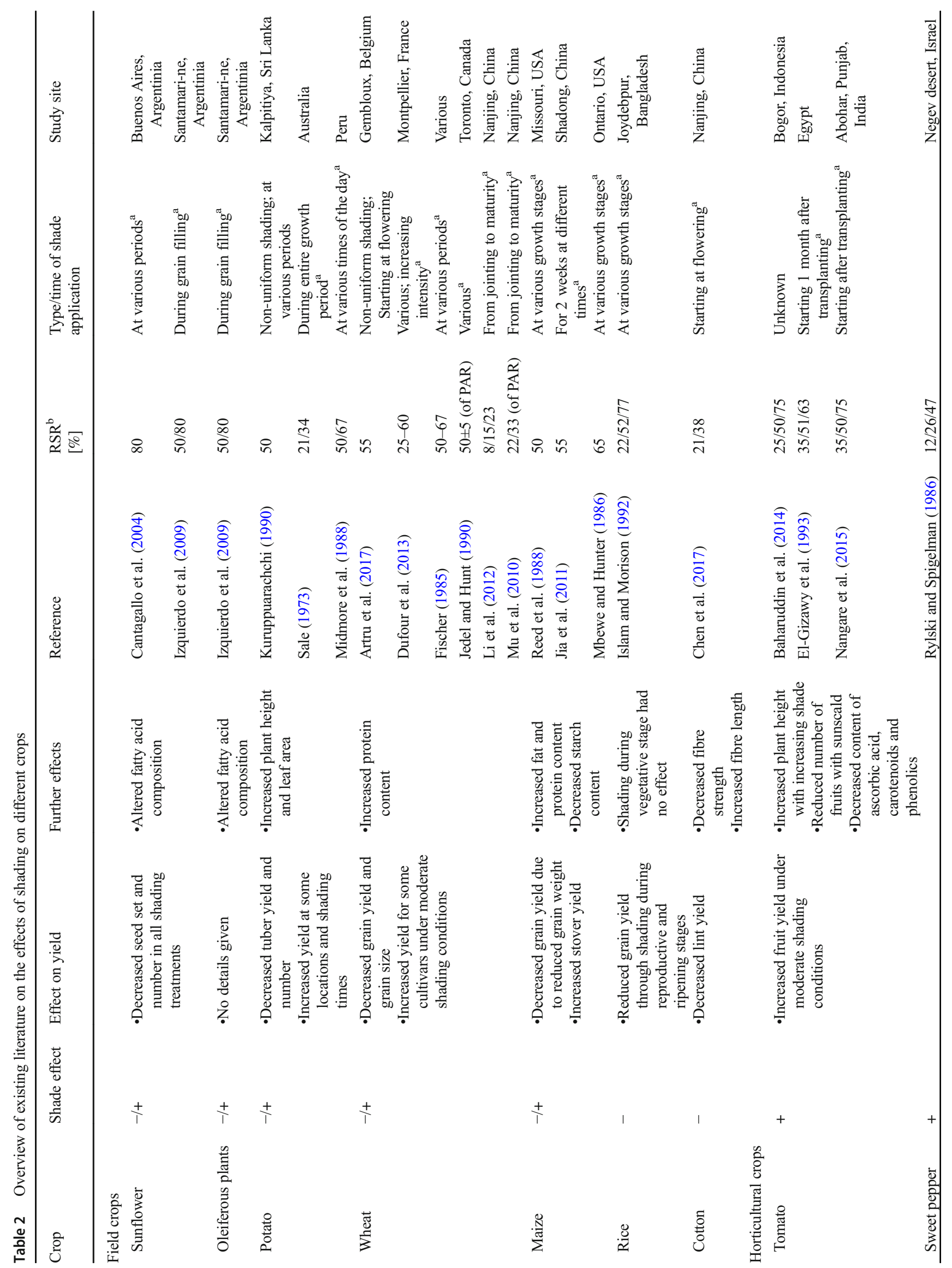

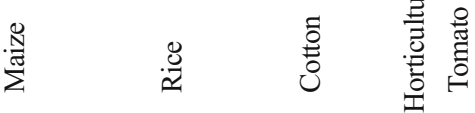




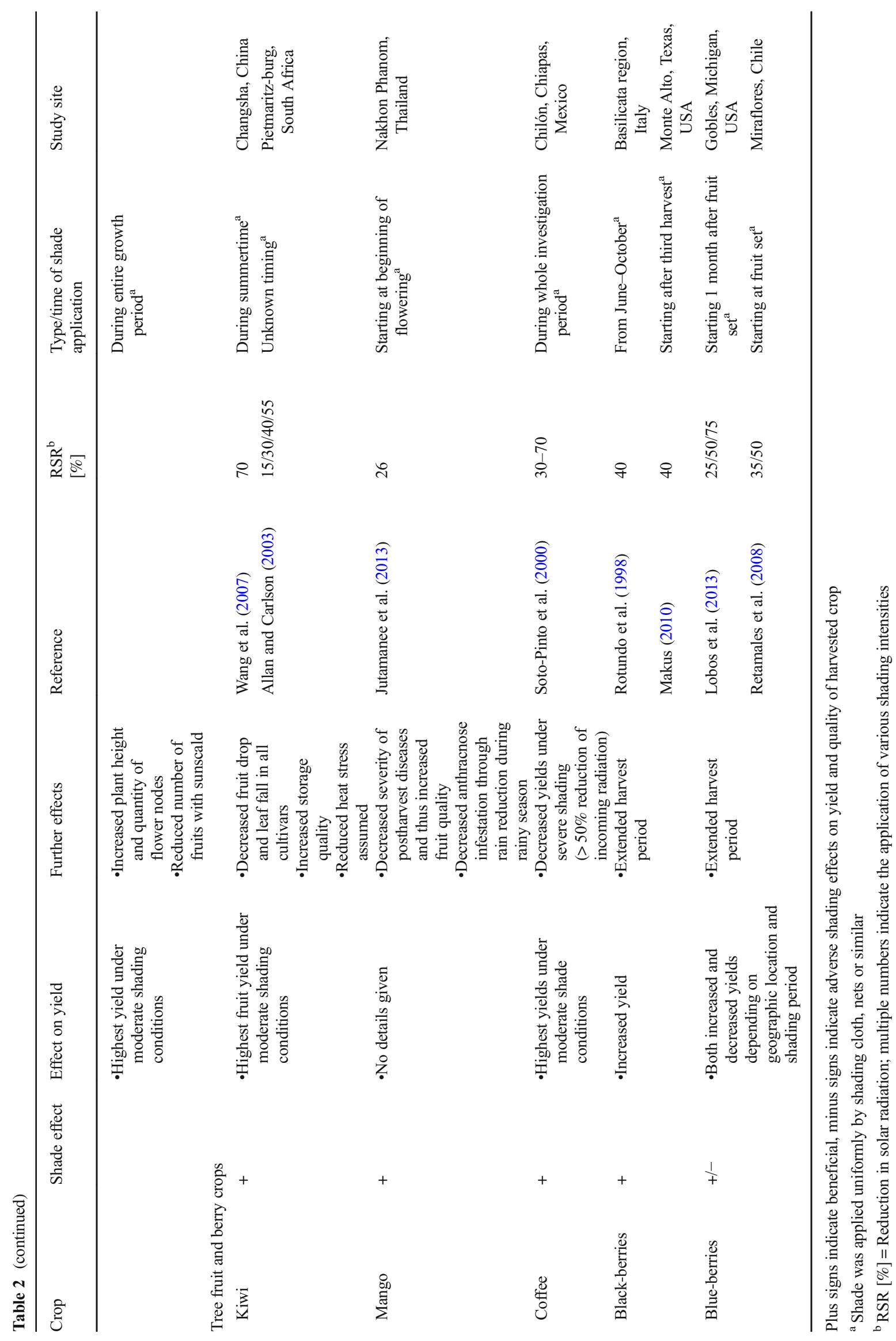


vegetative stage did not have any effects on yields (Islam and Morison 1992). In contrast, Li et al. (2012) found that grain yields of two wheat cultivars increased under mild shading conditions when applied from jointing to maturity ( $8 \%$ reduction of full sunlight). In maize, the extent of yield reductions was also linked to the growth stage at which shading was applied. Reed et al. (1988) found grain yield to be reduced by $12 \%$ when shading (50\% reduction of incoming radiation) was applied during the vegetative stage. When applied during flowering or grain filling, yields were reduced by $20 \%$ and 19\%, respectively (Reed et al. 1988). Mbewe and Hunter (1986) found similar results, with grain yield reductions in maize being most affected during the reproductive stage. Interestingly, while grain yields were reduced by $52 \%$ under shading (65\% reduction of incoming radiation), stover yield was almost unaffected by shading during the reproductive stage (Mbewe and Hunter 1986).

In potatoes, tuber number and tuber yield were generally decreased by shading (Kuruppuarachchi 1990; Midmore et al. 1988; Sale 1973), but in regions with a high solar irradiation, yields were increased when shading was applied either during early plant development (Kuruppuarachchi 1990) or around noon (Midmore et al. 1988). This effect was explained by an enhanced plant survival rate through shading. However, depending on the climate, potential effects of the PV canopy on microclimate e.g. observed changes in evapotranspiration, need to be taken into account when interpreting data (Marrou et al. 2013a). This applies, for example, to the findings of Marrou et al. (2013c), which resulted from experiments carried out under a dry Mediterranean climate. In tomatoes, fruit yield increased under moderate shading conditions (25-36\% reduction of full sunlight) in semi-arid conditions with high light intensities (Baharuddin et al. 2014; ElGizawy et al. 1993; Nangare et al. 2015). Plant height also increased under these conditions. However, a higher degree of shading (50-75\% of full sunlight) had adverse effects and led to decreased fruit yields. Similar results were found for sweet peppers grown in the Negev desert where moderate shade (12-26\% reduction of full sunlight) led to increased yields and plant heights (Rylski and Spigelman 1986).

Moreover, the impact of shading on yields seems to depend on the plant component harvested. For lettuce, harvestable yield of some varieties was found to be hardly affected by shading, whereas for other varieties the yield exceeded that of plants grown under full-sun conditions (Marrou et al. 2013c). Marrou et al. (2013c) concluded that this was linked to different mechanisms of how the varieties adapted to shaded conditions. Shade-tolerant varieties showed a number of adaption strategies including an increased total leaf area, an altered leaf orientation, and a modified morphology with longer, wider, thinner but lower number of leaves. In wheat, the maximum leaf area index was found to be unaffected by shading (Artru et al. 2017; Dufour et al. 2013), while the straw biomass of some varieties increased (Artru et al. 2017). For certain temperate grassland species, pot experiments with shading cloths showed that, depending on the variety, consistent or even higher yields can be achieved under moderate shade conditions (Pang et al. 2017; Semchenko et al. 2012). These findings were confirmed in the first year of our own APV experiments, where shading to the extent of about one third of PAR led to an increased vegetative plant biomass in wheat and celeriac, but barely affected total yields of clover grass. In maize, Mbewe and Hunter (1986) found stover yield to be almost unaffected depending on the growth stage at which shading was applied. Hence, the effect of shading on vegetative plant components should also be considered; potential benefits may be derived by selecting appropriate crop species and varieties. In particular, forage crops and leaf vegetables such as cabbage and lettuce may benefit from diminished solar irradiation by increasing leaf area and thus total plant biomass.

In addition to yield factors, shading influences the quality of the harvestable products. In wheat, shading correlated with increasing grain protein content (Artru et al. 2017; Dufour et al. 2013; Li et al. 2012); in maize kernels, both fat and protein content increased (Jia et al. 2011). One study also addressed the impact of shading on the baking quality of two different wheat cultivars ( $\mathrm{Li}$ et al. 2012): The glutenin content, wet gluten content, falling number and sedimentation value were all increased under moderate shading conditions, whereas mild shading ( $8 \%$ reduction of full sunlight) led to opposite results. These findings were explained by a dilution effect due to changes in grain weight, which was decreased by moderate and increased by mild shading (Li et al. 2012). In oil crops, oil quality was found to be modified through an altered fatty acid composition in response to changes in intercepted solar radiation (Gauthier et al. 2017; Izquierdo et al. 2009). The oleic acid content of maize, rape, soy and sunflower decreased with decreasing light intensity, whereas the content of polyunsaturated fatty acids such as linoleic and linolenic acid increased (Izquierdo et al. 2009). This result was recently confirmed by Gauthier et al. (2017) who also found the linolenic acid concentration of different oilseed rape genotypes to be negatively correlated with solar radiation. However, the effect of solar radiation was the reverse during the first 100-300 degree days after the beginning of flowering. Apart from the oil composition, shading was also associated with a reduced oil concentration (Gauthier et al. 2017). In purple- and red-fleshed potatoes, the content of anthocyanins and phenolics increased with higher light intensity (Reyes et al. 2004). This is in accordance with findings in tomatoes, where the content of various secondary plant metabolites, such as carotenoids (McCollum 1954), ascorbic acid (Hamnner et al. 1945) and phenolics (Dumas et al. 2003; Wilkens et al. 1996), increased with light intensity. For other quality-relevant factors of tomatoes, the results given in the 
literature are quite diverse. For example, El-Gizawy et al. (1993) found an increasing percentage of titratable acid and a decreasing content of both ascorbic acid and total soluble solids (TSS) with increasing shade, whereas Nangare et al. (2015) found no significant changes in acidity, TSS and ascorbic acid content. The occurrence of sunscald in tomatoes (ElGizawy et al. 1993) and sweet peppers (Rylski and Spigelman 1986) grown in Egypt and Israel (Negev desert), respectively, was found to be reduced under shaded compared to full-sun conditions, showing that shading most notably acts as protection from excessive solar radiation and high temperatures in the studied regions. For fruit trees such as kiwi and mango, moderate shade has been found to increase fruit quality (Jutamanee et al. 2013; Wang et al. 2007) and partly even yields (Allan and Carlson 2003). These findings have been associated with enhanced protection against adverse climatic conditions such as high temperatures and excessive rainfall.

As described above, altered microclimate conditions in an APV cultivation system may trigger several effects on crop yield and quality of the harvestable products. However, there are no data available for a large number of crop species. Moreover, as the results mainly stem from netting and agroforestry experiments, there are limits to their transferability to APV systems. This emphasizes the need for distinct investigations for crop cultivation under APV. Nevertheless, the most prevalent change affecting plant cultivation will be the restricted light availability, which will most likely lead to yield losses in the majority of cultivated crops. The extent of the losses will very much depend on the local climatic conditions, particularly solar radiation, and the technical implementation of the APV system. Especially in arid regions, where the negative effects of high solar irradiance and excessive water losses predominate, additional shading may be advantageous and lead to yield stability (Amaducci et al. 2018). As shading patterns and microclimatic conditions under APV differ between the seasons, the impact on crop production will also depend on whether the crops are cultivated in spring or summer (Dupraz et al. 2011b; Marrou et al. 2013c). It can be assumed that, in species that are well adapted to shade or respond with an enhanced vegetative biomass production, yields can be maintained or even increased. This could be the case for forage crops, herbaceous plants and leaf vegetables such as cabbage and lettuce. For some species, it may be possible to alleviate the predicted yield losses through shading by deferring the harvest and thus extending the vegetation period. This has recently been confirmed by Elamri et al. (2018), who found a slight delay in development of lettuce grown under APV. Comparable results have been found for blueberries and blackberries grown under shading nets, where shading led to extended harvest periods, and thus also potential benefits in terms of marketing, as higher market prices can be achieved (Lobos et al. 2013; Rotundo et al. 1998). Several medicinal and spice crops such as cardamom and pepper, which are traditionally grown in forests and thus well adapted to shade, are currently being investigated for cultivation in agroforestry systems. These could also be considered for cultivation in APV systems (Rao et al. 2004; Reyes et al. 2009; Singh et al. 1989). Coffee, one of the most important tropical cash crops worldwide, has been shown to benefit from the additional shade provided by cultivation in agroforestry systems (Jezeer et al. 2018; Soto-Pinto et al. 2000). Similar results have been found for speciality crops like blackberry and blueberry, which naturally occur in habitats with moderate light conditions (Lobos et al. 2013; Makus 2010; Retamales et al. 2008; Rotundo et al. 1998). While blackberry yields increased from 9 up to 34\% (Makus 2010; Rotundo et al. 1998), the results for blueberries are less distinct and seem to depend on climatic conditions and the period shading is applied (Lobos et al. 2013; Retamales et al. 2008). Even though the results from the various shading studies provide first insights into the shade tolerance of different crop species, they lack transferability due to the heterogeneity of climatic conditions and experimental set-up. In this context, crop models can be a more universal approach; they allow influencing variables to be varied without the time and effort required for extensive field experiments.

\subsection{Modelling approaches in APV research}

As outlined in the previous sections, the impact of APV on agronomic aspects is a quite complex topic and is influenced by many different factors. PV technology is steadily being refined, offering various options for the configuration of APV facilities adjusted to crop production. While the electrical performance of PV systems can nowadays be more or less easily calculated using existing software and models (Lalwani et al. 2010), the impacts on crop cultivation are more complex and thus, difficult to estimate. As seen in Section 2.3.3 and the corresponding Table 2, a number of studies have already addressed the topic of the impact of shading on crop cultivation. However, these studies were performed in different regions of the world and most were characterized by specific local climatic conditions. In this context, different solar radiation levels, temperatures, water availability etc. may also have affected the observed effects of shading. In addition, the manner in which the shading was applied also differs between the studies. While some apply uniform shading for the whole cropping period (e.g. Chen et al. 2017; Nangare et al. 2015), others use scattered shade limited to specific stages of crop development (e.g. Artru et al. 2017; Islam and Morison 1992). Therefore, the results of the cited studies are quite difficult to compare and even more in regard to the dynamic shading patterns in APV systems.

One approach to addressing the complexity and dynamism of APV systems is the development of crop models. This has already been initiated and further developed by a number of 
researchers (Dinesh and Pearce 2016; Dupraz et al. 2011a; Elamri et al. 2018; Elamri et al. 2017; Marrou et al. 2013a; Marrou et al. 2013c; Valle et al. 2017). The first modelling approach was introduced by Dupraz et al. (2011a). It consists of two different types of models to capture the complexity of APV. The so-called STICS model (Brisson et al. 2002) was used to simulate the impact of environmental variables on crop development, allowing the incorporation of crop specific parameters and the interaction of the crops with abiotic factors like microclimate, soil and farming practice (Dinesh and Pearce 2016; Flénet et al. 2004). A second model was used to predict light availability and distribution underneath an APV array. As shown by Dupraz et al. (2011a), crop modelling can be a useful tool for the simulation of crop performance under APV and, when combined with PV modelling and the LER approach, also allows the land productivity of the APV systems to be evaluated. However, they also revealed potential limits to the STICS model in the simulation of crop development under dense shading conditions (Dupraz et al. 2011a). The modelling approach has since been further developed by Marrou et al. (2013a, 2013b, 2013c), who adapted various models to the microclimatic dynamics underneath an APV system based on data obtained from their APV field trial. They implemented a comprehensive microclimatic monitoring system to measure incident radiation, air temperature, humidity, soil temperature and soil moisture at hourly intervals, thus achieving a high temporal resolution (Marrou et al. 2013a; Marrou et al. 2013b; Marrou et al. 2013c). In addition, wind speed, precipitation and crop specific parameters, such as stomatal conductance, crop cover rate and crop temperature were measured (Marrou et al. 2013b). They showed that the correlation of field data and their radiation model can be improved by increased spatial and temporal resolution of the measurements (Marrou et al. 2013c). To better understand the driving forces of water balance underneath APV, Marrou et al. (2013a) developed a theoretical model that identifies and calculates its components. Although rain distribution was observed to be quite heterogeneous under APV in these studies, rainwater inputs in the models were assumed to be similar to the unsheltered treatment (Marrou et al. 2013a). This was recently taken up by Elamri et al. (2017), who used data obtained from a field experiment addressing the rain distribution underneath an APV facility to design a rain distribution model. This enabled them to identify the key determinants of rain distribution caused by the PV panels and obtain a higher resolution of spatial heterogeneities in water supply underneath an APV system (Elamri et al. 2017; see also Section 2.3.1). In a follow-up study, Elamri et al. (2018) complemented this model with previous modelling approaches (Marrou et al. 2013a, 2013b, 2013c; Valle et al. 2017) giving a more complex model that incorporates a number of aspects including the impact of rain distribution, water and land use efficiency, as well the optimization of shading strategy (Elamri et al. 2018).
They concluded that the model produced satisfactory results with some room for improvement in the temporal resolution and incorporation of soil surface conditions to assess soil water distribution. Elamri et al. (2018) consider their model a useful tool for the dimensioning of APV systems as well as the optimisation of irrigation and panel adjustment, but for further evaluation of its universal applicability a sensitivity analysis is necessary (Elamri et al. 2018).

In recent years, the modelling approach in APV research has been developed and refined by several studies. It enables the simulation of the impacts of APV for specific local climatic conditions and the technical implementation. To improve the validity of simulated results, further field experiments are required to obtain sufficient data on microclimatic heterogeneities. First steps in this direction have already been made by Marrou et al. (2013c) and Elamri et al. (2017) who already have acquired data on several microclimatic factors. For a more precise spatial and temporal resolution, further variables e.g. soil surface status (Elamri et al. 2018), need to be incorporated and predicted values validated from field experiments with comprehensive microclimate monitoring. In this context, measurements should also be taken transverse to the solar panels of the APV facility, as already implemented by Elamri et al. (2017), to gather data on rain distribution. Although the microclimatic modelling of APV systems is already quite sophisticated, the modelling of crop performance is still insufficient. Most studies published so far only discuss the shade adaptive responses of lettuce during its vegetative phase (Elamri et al. 2018). There is a lack of information on more complex crops (Valle et al. 2017) and their light requirements during various stages of development, and this is neither addressed in modelling approaches nor validated under field conditions (Dinesh and Pearce 2016; Marrou et al. 2013a, 2013b, 2013c). For a better understanding of crop specific morphological traits and their response to altered light conditions during different stages of development, further field experiments with various crop species are necessary to obtain additional data on crop performance, which then can be used to improve validity of the crop models. Ultimately, this information needs to be gathered in overarching models that simulate both energy and crop performance as well as microclimatic impacts, taking into consideration the local climatic conditions, selected crops and technical implementation of the APV facility.

\section{Outlook and future application opportunities}

APV systems are still at an early stage of development and there is plenty of scope for technical improvements and further fields of application. As already described in Section 2.3.1, there have recently been several innovations in PV 
technology. Valle et al. (2017) have shown that dynamic PV modules with controlled tracking can optimize the availability of incident radiation on the plant canopy, allowing more efficient crop production and increasing both electricity and biomass yield. The application of wavelength-selective PV modules in horticulture is currently being investigated with the aim of further adjusting PV systems to the specific requirements of crops in co-productive systems (Loik et al. 2017). Electricity yield may also be increased by upgrading APV plants with wind turbines to combine wind and solar energy production (Rem Tec 2017b).

In addition to technical optimizations, there are various implementation opportunities for APV, depending on the local climatic conditions and the scale of the facility. For example, the power generated could be used to optimize the farm's existing operation flows e.g. processing of harvested products or energy-consuming processes such as cooling and ventilation (Mekhilef et al. 2013). Another possibility is the electrification of farm machinery or vehicles in general. The selfconsumption of electricity could be further increased by storage facility upgrades. In developing countries and other regions with only a rudimentary electrical grid, APV could act as a decentralized energy source for the electrification of rural areas (Malu et al. 2017; Silva Herran and Nakata 2012). This was also taken up by Harinarayana and Vasavi (2014), who see great potential for APV to meet future renewable energy targets in India, both improving rural off-grid energy production and saving on high expenditure for the expansion of the electricity grid. At farm level, the power could be utilized directly for irrigation and water-pumping systems or stored by pumping water into a reservoir to be used later for irrigation purposes (Burney et al. 2010; Mekhilef et al. 2013), thus helping to improve food security and water supply. Campana et al. $(2016,2017)$ recently investigated the potential of photovoltaic water-pumping systems for forage production in China. They concluded that these pumping systems provide great potential for the improvement of grassland productivity, while mitigating adverse effects of climate change and grassland desertification. In addition, the positive knock-on effects on $\mathrm{CO}_{2}$ emission reduction and sequestration are conceivable, when diesel-driven water-pumping systems are replaced (Campana et al. 2016, 2017). APV could also provide a useful contribution to the holistic agricultural approaches of organic farms or large-scale projects such as Sekem (Sekem 2017) and the Sahara Forest Project (Sahara Forest Project 2017), both of which strive to re-cultivate desert areas through agricultural production using innovative and sustainable technologies. As these projects are located in arid regions (Egypt and Jordan, respectively) potential synergistic effects of the APV panels on crop production can be expected through the mitigation of evaporation and excessive solar radiation (Marrou et al. 2013a; Ravi et al. 2016). This approach is also being pursued and practically implemented in large-scale projects in China
(Tonking New Energy 2018). Thus, APV could be an approach for sustainable desert agriculture. The described effects on crop production may also counteract the severe climatic conditions related to climate change, such as drought and heat. In the EU and other industrial countries, the development of renewable energies currently forms one of the key components of a sustainable climate and energy policy. Sustainability goals, combined with the limited agricultural land area in these countries, have led to an ethical conflict about land use for food or bioenergy production. This could be alleviated by the implementation of APV.

Another opportunity would be to exploit synergistic effects in cultivation systems that already use supporting structures, such as hop growing, horticulture (shade net houses and greenhouses), viticulture and intensive fruit production. The implementation of PV greenhouses is one focus of current research (Cossu et al. 2014; Kadowaki et al. 2012; UreñaSánchez et al. 2011) and has already been realized in several projects worldwide (Akuo Energy 2018; Reden Solar 2018; Tenergie 2018). Even though yields of horticultural crops, such as tomatoes and green onions, decrease, the economic benefits of these co-productive systems probably outweigh potential yield losses (Cossu et al. 2014; Kadowaki et al. 2012). As concluded in Section 2.3.3, the effects of shading will differ between crop species and local climatic conditions. The use of anti-hail nets is quite common in wine and fruit cultivation (Gandorfer et al. 2016; Kiprijanovski et al. 2016) and nettings are also applied as protection from other climate impacts such as excessive radiation, high temperatures (Ilić and Fallik 2017) and frost (Teitel et al. 1996). In these systems, synergistic effects can be achieved by the direct protection from adverse climatic effects through the PV panels themselves or by using the same supporting structures for both panels and netting. The impact of climate change on wine quality has recently been investigated, with canopy structures being one of the suggested solutions for protection against intense irradiation (van Leeuwen and Darriet 2016). This approach is already being pursued by the French company Sun'Agri (2018), one of the project partners in the French APV projects. They expect the application of APV in intensive fruit production and viticulture to lead to water savings, protect fruit against sunscald, and maintain or even increase yields by reducing losses due to weather extremes (frost, hail, strong wind). This aspect could become even more relevant in future in major wine-producing regions, as the area suitable for viticulture is predicted to decrease dramatically by 2050 due to the effects of climate change (Hannah et al. 2013). Another positive aspect in this context is that scaffolding is already accepted in these cultivation systems. A recent modelling study assigned these considerations to grape farming in India to ascertain its potential for APV (Malu et al. 2017). Malu et al. (2017) concluded that the annual income of grape farms using APV could be increased about 15 times through 
the additional energy production, while maintaining grape yields. However, it first needs to be proven that such predicted agricultural yields can really be achieved in practice.

The implementation of APV technology is likely to meet some obstacles. The introduction of new technologies is always accompanied by a certain amount of public controversy and this should also not be underestimated in the case of APV systems. In Germany, the uncontrolled expansion of groundmounted PV arrays has led to a diminishing acceptance within the population followed by legal restrictions concerning the construction of PV facilities. In addition, the installation of ground-mounted PV plants leads to the irreversible conversion of arable into surfaced land and consequently a loss of area payments granted by the EU Common Agricultural Policy (European Commission 2003). In this context, legal regulations for the construction of APV facilities need to be clarified to provide a clear distinction between groundmounted PV arrays and APV arrays. For APV, a certain minimum agricultural yield needs to be achieved in order to ensure sufficient crop production and avoid competition with energy production. Any kind of "pseudo agriculture" needs to be avoided, particularly with regard to agricultural subsidies. In our practical APV project, the farmers stated that they could tolerate crop yield reductions up to $20 \%$. However, as subjective perceptions and opinions will differ, limits for tolerable yield reductions have to be defined. Although there is a clear call within society for the development of renewable energies, there is often a lack of social acceptance at local level, particularly when a loss of visual landscape quality, damage to cultural landscapes or consequences for the environment are feared (Poti et al. 2012; Zoellner et al. 2008). Even though APV avoids the loss of arable land and the resulting conflicts between food and energy production, a change of landscape scenery cannot be denied and will inevitably lead to societal debates, especially in the case of large-scale plants, as seen in China (Huawei FusionSolar 2017). However, in contrast to ground-mounted PV facilities, APV will not be accompanied by a loss of wildlife as fencing is not necessary and would indeed be obstructive for agricultural practice (Turney and Fthenakis 2011). In cultivation systems with scaffolding structures, an extension by APV will probably be less controversial, as the presence of supports is already established. Another approach to improving social acceptance could be the selective embedding into the existing scenery, paying attention to local circumstances (Scognamiglio 2016). This can be achieved in several ways including specific designs, the usage of organic materials or dyeing of the PV cells (Scognamiglio 2016). As Zoellner et al. (2008) concluded from case studies in Germany, the acceptance of renewable energies can be improved by involving the general public in decision-making processes.

\section{Conclusion}

The application of APV systems offers a number of opportunities, which differ depending on regional and climatic conditions. The real added value of the APV technology is that it enables the simultaneous production of food and energy, providing undeniable economic benefits for farmers, with additional potential synergistic effects. This is of particular interest in densely populated industrial countries, where the expansion of renewable energies is becoming increasingly important, but productive farmlands need to be preserved. APV will inevitably lead to altered microclimatic conditions, notably a reduced solar radiation and resulting changes in water balance. As radiation is one of the most important factors affecting crop performance, a decline in agricultural yields is the most likely consequence of cultivation underneath an APV array. However, due to microclimatic heterogeneities under APV, results from shading experiments are only transferable to a limited extent. In dry years, microclimatic alterations under APV can contribute to yield stabilization, compensating for seasonal climatic and crop yield fluctuations. This may become even more important in the future with the anticipated change in climatic conditions. Furthermore, benefits are possible for shade-adapted crops and in hot, arid climates where enhanced water savings and protection against adverse effects of high temperatures and excessive radiation are of advantage. As only very few studies address the impact of this technology on crop yields and quality, further investigations incorporating different climatic conditions, crop species and varieties are indispensable for the evaluation of its applicability in prospective agricultural systems. Such investigations should also consider synergies with current innovations in PV technology and agriculture, as well as the inclusion of APV into different cultivation systems and processing cascades. In this context, modelling can be an efficient approach to process the results from field experiments into universal models, which then can be adapted to specific climatic conditions and technical implementations of APV systems, thus finding appropriate solutions for respective locations. However, APV can be an important component of future agricultural systems, addressing some of the major current and prospective societal and environmental challenges, such as climate change, global energy demand, food security and land use.

Acknowledgments Manuscript was written within the APV-RESOLA project that received funding from the German Federal Ministry for Education and Research (BMBF) under grant no. 033L098G. Thanks to Nicole Gaudet for revising the manuscript.

\section{Compliance with ethical standards}

Conflict of interest The authors declare that they have no conflict of interest. 


\section{References}

Akuo Energy (2018) AGRINERGIE®. http://www.akuoenergy.com/en/ agrinergie. Accessed 7 February 2018

Allan P, Carlson C (2003) Effects of shade level on kiwifruit leaf efficiency in a marginal area. Acta Hortic:509-516. https://doi.org/10. 17660/ActaHortic.2003.610.68

Amaducci S, Yin X, Colauzzi M (2018) Agrivoltaic systems to optimise land use for electric energy production. Appl Energy 220:545-561. https://doi.org/10.1016/j.apenergy.2018.03.081

Arauz LF (2000) Mango anthracnose: economic impact and current options for integrated management. Plant Dis 84:600-611. https://doi. org/10.1094/PDIS.2000.84.6.600

Armstrong A, Ostle NJ, Whitaker J (2016) Solar park microclimate and vegetation management effects on grassland carbon cycling. Environ Res Lett 11(74016). https://doi.org/10.1088/1748-9326/ 11/7/074016

Artru S, Garré S, Dupraz C, Hiel M-P, Blitz-Frayret C, Lassois L (2017) Impact of spatio-temporal shade dynamics on wheat growth and yield, perspectives for temperate agroforestry. Eur J Agron 82:60 70. https://doi.org/10.1016/j.eja.2016.10.004

Baharuddin R, A Chozin M, Syukur M (2014) Shade tolerance of 20 genotypes of tomato (Lycopersicon esculentum Mill), $132 \mathrm{pp}$.

Barron-Gafford GA, Minor RL, Allen NA, Cronin AD, Brooks AE, Pavao-Zuckerman MA (2016) The photovoltaic Heat Island effect: larger solar power plants increase local temperatures. Sci Rep 6(35070). https://doi.org/10.1038/srep35070

Beck M, Bopp G, Goetzberger A, Obergfell T, Reise C, Schindele S (2012) Combining PV and food crops to agrophotovoltaic - optimization of orientation and harvest. 5 pages / 27th European photovoltaic Solar Energy conference and exhibition; 4096-4100. https://doi. org/10.4229/27thEUPVSEC2012-5AV.2.25

Blankenship R, Tiede D, Barber J, W Brudvig G, Fleming G, Ghirardi M, Gunner M, Junge W, Kramer D, Melis A, Moore T, Moser C, G Nocera D, Nozik A, R Ort D, Parson W, Prince R, Sayre R (2011) Comparing photosynthetic and photovoltaic efficiencies and recognizing the potential for improvement. Science (New York, NY) 332. https://doi.org/10.1126/science.1200165

BMWi (2016) Renewable energy sources in figures: national and international development, 2016, $80 \mathrm{pp}$.

Brisson N, Gate P, Lorgeou J, Nicoullaud B, Tayot X, Plenet D, Bouthier A, Ripoche D, Mary B, Justes E (2002) STICS: A generic model for simulating crops and their water and nitrogen balances. II. Model validation for wheat and maize. Agronomie 22. https://doi.org/10. 1051/agro:2001005

Burney J, Woltering L, Burke M, Naylor R, Pasternak D (2010) Solarpowered drip irrigation enhances food security in the Sudano-Sahel. Proc Natl Acad Sci U S A 107:1848-1853. https://doi.org/10.1073/ pnas.0909678107

Campana PE, Leduc S, Kim M, Olsson A, Zhang J, Liu J, Kraxner F, McCallum I, Li H, Yan J (2017) Suitable and optimal locations for implementing photovoltaic water pumping systems for grassland irrigation in China. Appl Energy 185:1879-1889. https://doi.org/ 10.1016/j.apenergy.2016.01.004

Campana PE, Olsson A, Li H, Yan J (2016) An economic analysis of photovoltaic water pumping irrigation systems. Int J Green Energy 13:831-839. https://doi.org/10.1080/15435075.2016.1161631

Cantagallo JE, Medan D, Hall AJ (2004) Grain number in sunflower as affected by shading during floret growth, anthesis and grain setting. Field Crops Research 85:191-202. https://doi.org/10.1016/S03784290(03)00160-6

Casarin D (2012) R.E.M. Racconta 1"“Agrovoltaico": Quando l'Agricoltura Scopre il Fotovoltaico. http://www.genitronsviluppo. com/2012/07/30/rem-agrovoltaico/. Accessed 29 November 2017
Chen BL, Yang HK, Ma YN, Liu JR, Lv FJ, Chen J, Meng YL, Wang YH, Zhou ZG (2017) Effect of shading on yield, fiber quality and physiological characteristics of cotton subtending leaves on different fruiting positions. Photosynthetica 55:240-250. https://doi.org/10. 1007/s11099-016-0209-7

Corditec (2017) Our plant - Campo d'Eco. http://corditec.it/solare/pagecampo.php?page $=$ impianto \& title $=$ campo $\% 20 \mathrm{~d} \% 27 \mathrm{eco} \& \mathrm{id}=77$. Accessed 29 November 2017

Cossu M, Murgia L, Ledda L, Deligios PA, Sirigu A, Chessa F, Pazzona A (2014) Solar radiation distribution inside a greenhouse with southoriented photovoltaic roofs and effects on crop productivity. Appl Energy 133:89-100. https://doi.org/10.1016/j.apenergy.2014.07.070

Cossu M, Yano A, Li Z, Onoe M, Nakamura H, Matsumoto T, Nakata J (2016) Advances on the semi-transparent modules based on micro solar cells: first integration in a greenhouse system. Appl Energy 162:1042-1051. https://doi.org/10.1016/j.apenergy.2015.11.002

Dinesh H, Pearce JM (2016) The potential of agrivoltaic systems. Renew Sust Energ Rev 54:299-308. https://doi.org/10.1016/j.rser.2015.10. 024

Du F, Deng W, Yang M, Wang H, Mao R, Shao J, Fan J, Chen Y, Fu Y, Li $\mathrm{C}, \mathrm{He} \mathrm{X}, \mathrm{Zhu} \mathrm{Y}$, Zhu S (2015) Protecting grapevines from rainfall in rainy conditions reduces disease severity and enhances profitability. Crop Prot 67:261-268. https://doi.org/10.1016/j.cropro.2014.10.024

Dufour L, Metay A, Talbot G, Dupraz C (2013) Assessing light competition for cereal production in temperate agroforestry systems using experimentation and crop modelling. J Agro Crop Sci 199:217-227. https://doi.org/10.1111/jac. 12008

Dumas Y, Dadomo M, Di Lucca G, Grolier P (2003) Effects of environmental factors and agricultural techniques on antioxidant content of tomatoes. J Sci Food Agric 83:369-382. https://doi.org/10.1002/jsfa.1370

Dupraz C, Marrou H, Talbot G, Dufour L, Nogier A, Ferard Y (2011a) Combining solar photovoltaic panels and food crops for optimising land use: towards new agrivoltaic schemes. Renew Energy 36: 2725-2732. https://doi.org/10.1016/j.renene.2011.03.005

Dupraz C, Talbot G, Marrou H, Wery J, Roux S, Fabien L, Ferard Y, Nogier A (2011b) To mix or not to mix: evidences for the unexpected high productivity of new complex agrivoltaic and agroforestry systems, $202 \mathrm{pp}$

Ehret M, Graß R, Wachendorf M (2015) The effect of shade and shade material on white clover/perennial ryegrass mixtures for temperate agroforestry systems. Agrofor Syst 89:557-570. https://doi.org/10 1007/s10457-015-9791-0

Elamri Y, Cheviron B, Lopez J-M, Dejean C, Belaud G (2018) Water budget and crop modelling for agrivoltaic systems: application to irrigated lettuces. Agric Water Manag 208:440-453. https://doi.org/ 10.1016/j.agwat.2018.07.001

Elamri Y, Cheviron B, Mange A, Dejean C, Liron F, Belaud G (2017) Rain concentration and sheltering effect of solar panels on cultivated plots. Hydrol Earth Syst Sci Discuss:1-37. https://doi.org/10.5194/ hess-2017-418

El-Gizawy AM, Abdallah MMF, Gomaa HM, Mohamed SS (1993) Effect of different shading levels on tomato plants. 2. Yield and fruit quality. https://doi.org/10.17660/ActaHortic.1993.323.32

Energieagentur Ravensburg gGmbH (2012) Energie- und Klimaschutzkonzept für die Region Bodensee-Oberschwaben: Umsetzung der Energiewende 2022 12, Ravensburg, 50 pp.

European Commission (2003) Agriculture and rural development: crosscompliance. https://ec.europa.eu/agriculture/direct-support/crosscompliance_en. Accessed 19 December 2017

Fischer RA (1985) Number of kernels in wheat crops and the influence of solar radiation and temperature. J Agric Sci 105:447. https://doi.org/ $10.1017 / \mathrm{S} 0021859600056495$

Flénet, F., Villon, P., Ruget, F., 2004. Methodology of adaptation of the STICS model to a new crop: spring linseed (Linum usitatissimum, L.). https://doi.org/10.1051/agro:2004032 24. https://doi.org/10. 1051/agro:2004032 
Fraunhofer Chile Research (2017a) AGROPV SUB v2: AgroPV: Energía Solar para una Agricultura Sustentable. https://www.youtube.com/ watch?v=3W4dvx3Og2I. Accessed 30 November 2017

Fraunhofer Chile Research (2017b) Presentación Proyecto Fic AGRO PV Región Metropolitana: AVANCE DE PROYECTO, March 2017

Fraunhofer Chile Research, 2017c. FIC AgroPV - FIC Region Metropolitana. https://www.smart-agropv.com/principal/1/ resultados agropvr15/. Accessed 31 May 2019

Fraunhofer ISE (2015) Current and future cost of photovoltaics. Longterm scenarios for market development. In: System prices and LCOE of utility-scale PV systems: study on behalf of agora Energiewende

Fraunhofer ISE (2017) Ein Jahr Agrophotovoltaik: Sonnenernte auf zwei Etagen. http://blog.innovation4e.de/2017/11/21/ein-jahragrophotovoltaik-sonnenernte-auf-zwei-etagen/. Accessed 30 November 2017

Gandorfer M, Hartwich A, Bitsch V (2016) Hail risk management in fruit production: anti-hail net versus hail insurance in Germany. Acta Hortic:141-146. https://doi.org/10.17660/ActaHortic.2016.1132.19

Gauthier M, Pellet D, Monney C, Herrera JM, Rougier M, Baux A (2017) Fatty acids composition of oilseed rape genotypes as affected by solar radiation and temperature. Field Crop Res 212:165-174. https://doi.org/10.1016/j.fcr.2017.07.013

Goetzberger A, Zastrow A (1982) On the coexistence of solar-energy conversion and plant cultivation. Int J Solar Energy 1:55-69. https://doi.org/10.1080/01425918208909875

Hamnner KC, Bernstein LA, Maynaed L (1945) Effects of light intensity, day length, temperature, and other environment factors on the ascorbic acid content of tomatoes. J Nutrition 29

Hannah L, Roehrdanz PR, Ikegami M, Shepard AV, Shaw MR, Tabor G, Zhi L, Marquet PA, Hijmans RJ (2013) Climate change, wine, and conservation. Proc Natl Acad Sci U S A 110:6907-6912. https://doi. org/10.1073/pnas.1210127110

Harinarayana T, Vasavi KSV (2014) Solar energy generation using agriculture cultivated lands. SGRE 05:31-42. https://doi.org/10.4236/ sgre.2014.52004

Hassanpour Adeh E, Selker JS, Higgins CW (2018) Remarkable agrivoltaic influence on soil moisture, micrometeorology and water-use efficiency. PLoS One 13:e0203256. https://doi.org/10. 1371/journal.pone.0203256

Homma M, Doi T, Yoshida Y (2016) A field experiment and the simulation on agrivoltaic-systems regarding to rice in a paddy field. J Jpn Soc Energy Resour 37:23-31. https://doi.org/10.24778/jjser.37.6_ 23

Huawei FusionSolar (2017) Fusion solar smart PV solution cases global EN 20170524. https://www.youtube.com/watch?v=DqecyiWjy8M. Accessed 12 June 2018

Ilić ZS, Fallik E (2017) Light quality manipulation improves vegetable quality at harvest and postharvest: a review. Environ Exp Bot 139: 79-90. https://doi.org/10.1016/j.envexpbot.2017.04.006

Islam MS, Morison JIL (1992) Influence of solar radiation and temperature on irrigated rice grain yield in Bangladesh. Field Crop Res 30: 13-28. https://doi.org/10.1016/0378-4290(92)90053-C

Izquierdo NG, Aguirrezábal LAN, Andrade FH, Geroudet C, Valentinuz O, Pereyra Iraola M (2009) Intercepted solar radiation affects oil fatty acid composition in crop species. Field Crop Res 114:66-74. https://doi.org/10.1016/j.fcr.2009.07.007

Jedel PE, Hunt LA (1990) Shading and thinning effects on multi- and standard-floret winter wheat. Crop Sci:128-133. https://doi.org/10. 2135/cropsci1990.0011183X003000010029x

Jezeer RE, Santos MJ, Boot RGA, Junginger M, Verweij PA (2018) Effects of shade and input management on economic performance of small-scale Peruvian coffee systems. Agric Syst 162:179-190. https://doi.org/10.1016/j.agsy.2018.01.014

Jia S-f, Li C-f, Dong S-t, Zhang J-w (2011) Effects of shading at different stages after anthesis on maize grain weight and quality at cytology level. Agric Sci China 10:58-69. https://doi.org/10.1016/S16712927(11)60307-6

Jutamanee K, Onnom S, Yingjajaval S, Sangchote S (2013) Leaf photosynthesis and fruit quality of mango growing under field or plastic roof condition. Acta Hortic:415-420. https://doi.org/10.17660/ ActaHortic.2013.975.53

Kadowaki M, Yano A, Ishizu F, Tanaka T, Noda S (2012) Effects of greenhouse photovoltaic array shading on welsh onion growth. Biosyst Eng 111:290-297. https://doi.org/10.1016/j. biosystemseng.2011.12.006

Kim Y-U, Seo B-S, Choi D-H, Ban H-Y, Lee B-W (2017) Impact of high temperatures on the marketable tuber yield and related traits of potato. Eur J Agron 89:46-52. https://doi.org/10.1016/j.eja.2017.06. 005

Kinney K, Minor R, Barron-Gafford G (2016) Testing predictions used to build an agrivoltaics installation on a small-scale educational model. University of Montana http://digitalcommons.calpoly.edu/star/386/. Accessed 12 February 2018

Kiprijanovski M, Gjamovski V, Arsov T (2016) The effects of anti-hail net in protection of pear orchard after hailstorm occurrence. Acta Hortic:529-534. https://doi.org/10.17660/ActaHortic.2016.1139.91

Krauss A, Marschner H (1984) Growth rate and carbohydrate metabolism of potato tubers exposed to high temperatures. Potato Res 27:297303. https://doi.org/10.1007/BF02357638

Kuruppuarachchi DSP (1990) Intercropped potato (Solanum spp.)" effect of shade on growth and tuber yield in the northwestern regosol belt of Sri Lanka. Field Crop Res 25, 61-72. https://doi.org/10.1016/ 0378-4290(90)90072-J

Lalwani M, Kothari DP, Singh M (2010) Investigation of solar photovoltaic simulation softwares. Int J Appl Eng Res 1

Li X, Cai J, Li H, Bo Y, Liu F, Jiang D, Dai T, Cao W (2012) Effect of shading from jointing to maturity on high molecular weight glutenin subunit accumulation and glutenin macropolymer concentration in grain of winter wheat. J Agron Crop Sci 198:68-79. https://doi.org/ 10.1111/j.1439-037X.2011.00484.x

Li Z, Yano A, Cossu M, Yoshioka H, Kita I, Ibaraki Y (2018) Shading and electric performance of a prototype greenhouse blind system based on semi-transparent photovoltaic technology. J Agric Meteorol 74:114-122. https://doi.org/10.2480/agrmet.D-17-00047

Lobos GA, Retamales JB, Hancock JF, Flore JA, Romero-Bravo S, del Pozo A (2013) Productivity and fruit quality of Vaccinium corymbosum cv. Elliott under photo-selective shading nets. Sci Hortic 153:143-149

Loik ME, Carter SA, Alers G, Wade CE, Shugar D, Corrado C, Jokerst D, Kitayama C (2017) Wavelength-selective solar photovoltaic systems: powering greenhouses for plant growth at the food-energywater nexus. Earth's Future 5:1044-1053. https://doi.org/10.1002/ 2016EF000531

Majumdar D, Pasqualetti MJ (2018) Dual use of agricultural land: introducing 'agrivoltaics' in Phoenix metropolitan statistical area, USA. Landsc Urban Plan 170:150-168. https://doi.org/10.1016/j. landurbplan.2017.10.011

Makus DJ (2010) Weed control and canopy light management in blackberries. Int J Fruit Sci 10:177-186

Malu PR, Sharma US, Pearce JM (2017) Agrivoltaic potential on grape farms in India. Sustainable Energy Technologies and Assessments 23:104-110. https://doi.org/10.1016/j.seta.2017.08.004

Marrou H, Dufour L, Wery J (2013a) How does a shelter of solar panels influence water flows in a soil-crop system? Eur J Agron 50:38-51. https://doi.org/10.1016/j.eja.2013.05.004

Marrou H, Guilioni L, Dufour L, Dupraz C, Wery J (2013b) Microclimate under agrivoltaic systems: is crop growth rate affected in the partial shade of solar panels? Agric For Meteorol 177:117-132. https://doi. org/10.1016/j.agrformet.2013.04.012

Marrou H, Wery J, Dufour L, Dupraz C (2013c) Productivity and radiation use efficiency of lettuces grown in the partial shade of 
photovoltaic panels. Eur J Agron 44:54-66. https://doi.org/10.1016/ j.eja.2012.08.003

Mbewe DMN, Hunter RB (1986) The effect of shade stress on the performance of corn for silage versus grain. Can J Plant Sci 66:53-60

McCollum JP (1954) Effects of light on the formation of carotenoids in tomato fruits. J Food Sci 19:182-189. https://doi.org/10.1111/j. 1365-2621.1954.tb17437.x

Mead R, Willey RW (1980) The concept of a 'land equivalent ratio' and advantages in yields from intercropping. Ex Agric 16:217. https:// doi.org/10.1017/S0014479700010978

Medina CL, Souza RP, Machado EC, Ribeiro RV, Silva JAB (2002) Photosynthetic response of citrus grown under reflective aluminized polypropylene shading nets. Sci Hortic 96:115-125. https://doi.org/ 10.1016/S0304-4238(02)00085-7

Mekhilef S, Faramarzi SZ, Saidur R, Salam Z (2013) The application of solar technologies for sustainable development of agricultural sector. Renew Sust Energ Rev 18:583-594. https://doi.org/10.1016/j.rser. 2012.10.049

Midmore DJ, Berrios D, Roca J (1988) Potato (Solanum spp.) in the hot tropics V. intercropping with maize and the influence of shade on tuber yields. Field Crop Res 18:159-176. https://doi.org/10.1016/ 0378-4290(88)90006-8

Movellan J (2013) Japan next-generation farmers cultivate crops and solar energy. http://www.renewableenergyworld.com/articles/2013/ 10/japan-next-generation-farmers-cultivate-agriculture-and-solarenergy.html. Accessed 14 July 2017

Mu H, Jiang D, Wollenweber B, Dai T, Jing Q, Cao W (2010) Long-term low radiation decreases leaf photosynthesis, photochemical efficiency and grain yield in winter wheat. J Agron Crop Sci 196:38-47. https://doi.org/10.1111/j.1439-037X.2009.00394.x

Nangare DD, Singh J, Meena VS, Bhushan B, Bhatnagar PR (2015) Effect of green shade nets on yield and quality of tomato (Lycopersicon esculentum Mill) in semi-arid region of Punjab. Asian J Adv Basic Applied Sci 1:1-8

Nonhebel S (2005) Renewable energy and food supply: will there be enough land? Renew Sust Energ Rev 9:191-201. https://doi.org/ 10.1016/j.rser.2004.02.003

Obergfell T, Bopp G, Reise C, Schindele S (Eds.), (2017) Landwirtschaft unter Photovoltaik - die weltweit erste APV-Forschungsanlage im Reallabor, $15 \mathrm{pp}$.

Pallone T (2017) Agrivoltaics: how plants grown under Solar panels can benefit humankind. http://insights.globalspec.com/article/4802/ agrivoltaics-how-plants-grown-under-solar-panels-can-benefithumankind?id=-777656564. Accessed 8 February 2018

Pang K, van Sambeek JW, Navarrete-Tindall NE, Lin C-H, Jose S, Garrett HE (2017) Responses of legumes and grasses to non-, moderate, and dense shade in Missouri, USA. I. Forage yield and its species-level plasticity. Agrofor Syst 88(287). https://doi.org/10. 1007/s10457-017-0067-8

Park KE, Kang GH, Kim HI, Yu GJ, Kim JT (2010) Analysis of thermal and electrical performance of semi-transparent photovoltaic (PV) module. Energy 35:2681-2687. https://doi.org/10.1016/j.energy. 2009.07.019

Poti B, Difiore M, Brohmann B, Heiskanen E, Raven R (2012) Towards a new methodology for creating societal acceptance of new energy project

Praderio S, Perego A (2017) Photovoltaics and the agricultural landscape: the agrovoltaico concept. http://www.remtec.energy/en/2017/08/28/ photovoltaics-form-landscapes/. Accessed 6 April 2018

Rao MR, Palada MC, Becker BN (2004) Medicinal and aromatic plants in agroforestry systems. Agrofor Syst 61-62:107-122. https://doi. org/10.1023/B:AGFO.0000028993.83007.4b

Ravi S, Macknick J, Lobell D, Field C, Ganesan K, Jain R, Elchinger M, Stoltenberg B (2016) Colocation opportunities for large solar infrastructures and agriculture in drylands. Appl Energy 165:383-392. https://doi.org/10.1016/j.apenergy.2015.12.078
Reden Solar. Photovoltaic greenhouses : an intelligent agro-energy solution. http://reden.solar/index.php/en/our-activities/\#photovoltaicshelters. Accessed 5 February 2018

Reed, A.J., Singletary, G., Schussler, J., R. Williamson, D., Christy, A.L., 1988. Shading effects on dry matter and nitrogen partitioning, kernel number, and yield of maize. CROP science - CROP SCI 28. https:// doi.org/10.2135/cropsci1988.0011183X002800050020x

Rem Tec (2017a) AGROVOLTAICO® TECHNOLOGY. https://www. remtec.energy/en/agrovoltaico/. Accessed 29 November 2017

Rem Tec (2017b) Wind agrovoltaico. https://www.remtec.energy/en/ agrovoltaico-2/wind-agrovoltaico/. Accessed 5 April 2018

Retamales JB, Montecino JM, Lobos GA, Rojas LA (Eds.) (2008) Colored shading nets increase yields and profitability of highbush blueberries. International Society for Horticultural Science (ISHS), Leuven, Belgium, 193-197

Reyes LF, Miller JC, Cisneros-Zevallos L (2004) Environmental conditions influence the content and yield of anthocyanins and total phenolics in purple- and red-flesh potatoes during tuber development. Am J Potato Res 81:187-193. https://doi.org/10.1007/BF02871748

Reyes T, Quiroz R, Luukkanen O, de Mendiburu F (2009) Spice crops agroforestry systems in the east Usambara Mountains, Tanzania: growth analysis. Agrofor Syst 76:513-523. https://doi.org/10. 1007/s10457-009-9210-5

Rotundo A, Forlani M, Di Vaio C (Eds.) (1998) Internationla Society for Horticultural Science (ISHS), Leuven, Belgium, 333-340

Rylski I, Spigelman M (1986) Effect of shading on plant development, yield and fruit quality of sweet pepper grown under conditions of high temperature and radiation. Sci Hortic 29:31-35. https://doi.org/ 10.1016/0304-4238(86)90028-2

Sahara Forest Project (2017) https://www.saharaforestproject.com/. Accessed 18 December 2017

Sale PJM (1973) Productivity of vegetable crops in a region of high solar input I. Growth and development of the potato (Solanum Tuberosum L.). Aust J Agric Res:733-749

Santra P, Pande P, Kumar S, Mishra D, Singh R (2017) Agri-voltaics or solar farming: the concept of integrating solar PV based electricity generation and crop production in a single land use system. Int J Renew Energy Res 7

Schmid A, Reise C, (2015) Bifacial PV modules - characterization and simulation. Fraunhofer ISE, 2 pp. https://www.ise.fraunhofer.de/ content/dam/ise/en/documents/information-material/Photovoltaics/ 16 en ISE Flyer Bifacial Modules.pdf. Accessed 9 November 2018

Scognamiglio A (2016) 'Photovoltaic landscapes': design and assessment. A critical review for a new transdisciplinary design vision. Renew Sust Energ Rev 55:629-661. https://doi.org/10.1016/j.rser. 2015.10.072

Sekem (2017) Sustainable development since 1977. http://www.sekem. com/en/index/. Accessed 18 December 2017

Semchenko M, Lepik M, Götzenberger L, Zobel K (2012) Positive effect of shade on plant growth: amelioration of stress or active regulation of growth rate? J Ecol 100:459-466. https://doi.org/10.1111/j.13652745.2011.01936.x

Silva Herran D, Nakata T (2012) Design of decentralized energy systems for rural electrification in developing countries considering regional disparity. Appl Energy 91:130-145. https://doi.org/10.1016/j. apenergy.2011.09.022

Singh KA, Rai RN, Patiram B, D.T (1989) Large cardamom (Amomum subulatum Roxb.) plantation - an age old agroforestry system in eastern Himalayas. Agrofor Syst 9:241-257. https://doi.org/10. 1007/BF00141087

Soto-Pinto L, Perfecto I, Castillo-Hernandez J, Caballero-Nieto J (2000) Shade effect on coffee production at the northern Tzeltal zone of the state of Chiapas, Mexico. Agric Ecosyst Environ 80:61-69. https:// doi.org/10.1016/S0167-8809(00)00134-1 
Sun'Agri (2018) L'agrivoltaïque. https://sunagri.fr/agrivoltaique/conceptagrivoltaique-dynamique/\#. Accessed 5 February 2018

Teitel M, Peiper UM, Zvieli Y (1996) Shading screens for frost protection. Agric For Meteorol 81:273-286. https://doi.org/10.1016/01681923(95)02321-6

Tenergie. Nos offres: L'offre « Serres photovoltaïques ». http://www. tenergie.fr/offers.php. Accessed 5 February 2018

The University of Arizona (2018) Biosphere 2. http://biosphere2.org/. Accessed 8 February 2018

Tonking New Energy (2018) Changshan PV station. http://tonkingtech. com/english/news_show.aspx? newsCateid=117\&cateid $=$ $117 \&$ NewsId $=137$. Accessed 9 February 2018

Tricoles R, (2017) UA Researchers Plant Seeds to Make Renewable Energy More Efficient: Agrivoltaics, an experiment in combining agriculture with energy efficiency, involves growing plants beneath solar panels. The University of Arizona. https://uanews.arizona.edu/ story/ua-researchers-plant-seeds-make-renewable-energy-moreefficient. Accessed 31 May 2019

Turney D, Fthenakis V (2011) Environmental impacts from the installation and operation of large-scale solar power plants. Renew Sust Energ Rev 15:3261-3270. https://doi.org/10.1016/j.rser.2011.04. 023

Ureña-Sánchez, R., Callejon-Ferre, Á.J., Pérez-Alonso, J., CarreñoOrtega, Á., 2011. Greenhouse tomato production with electricity generation by roof-mounted flexible solar panels. Sci Agric 69. https://doi.org/10.1590/S0103-90162012000400001
Valle B, Simonneau T, Sourd F, Pechier P, Hamard P, Frisson T, Ryckewaert M, Christophe A (2017) Increasing the total productivity of a land by combining mobile photovoltaic panels and food crops. Appl Energy 206:1495-1507. https://doi.org/10.1016/j. apenergy.2017.09.113

van Leeuwen C, Darriet P (2016) The impact of climate change on viticulture and wine quality. J Wine Econ 11:150-167. https://doi.org/ 10.1017/jwe.2015.21

Wang Z-Y, Yuan F-R, He K-J, Bu F-W (2007) Effects of overhead shading on yield and fruit quality of kiwifruit in regions with high temperatures in summer. Acta Hortic:399-407. https://doi.org/10. 17660/ActaHortic.2007.753.51

Wilkens RT, Spoerke JM, Stamp NE (1996) Differential responses of growth and two soluble phenolics of tomato to resource availability. Ecology 77:247-258. https://doi.org/10.2307/2265674

Zoellner J, Schweizer-Ries P, Wemheuer C (2008) Public acceptance of renewable energies: results from case studies in Germany. Energy Policy 36:4136-4141. https://doi.org/10.1016/j.enpol.2008.06.026

Publisher's note Springer Nature remains neutral with regard to jurisdictional claims in published maps and institutional affiliations. 